\title{
تأثير الذكاء الوجداني في القدرة على القيادة التربوية لدى مديري المدارس بسلطنة عُمان
}

\section{حمد بن حمود بن سليمان الغافري}

أستاذ مساعد- الجاهعة العربية المفتوحة- سلطنة عُمان

hamad@aou.edu.om 
تأثير الذكاء الوجداني في القدرة على القيادة التربوية لدى مديري المدارس بسلطنة عُمان

\section{حمد بن حمود بن سليمان الغافري}

أستاذ مساعد- الجامعة العربية المفتوحة- سلطنة عُمان

hamad@aou.edu.om

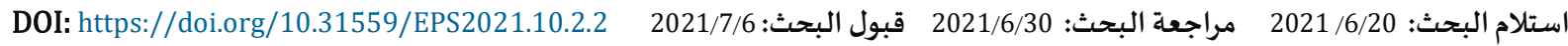

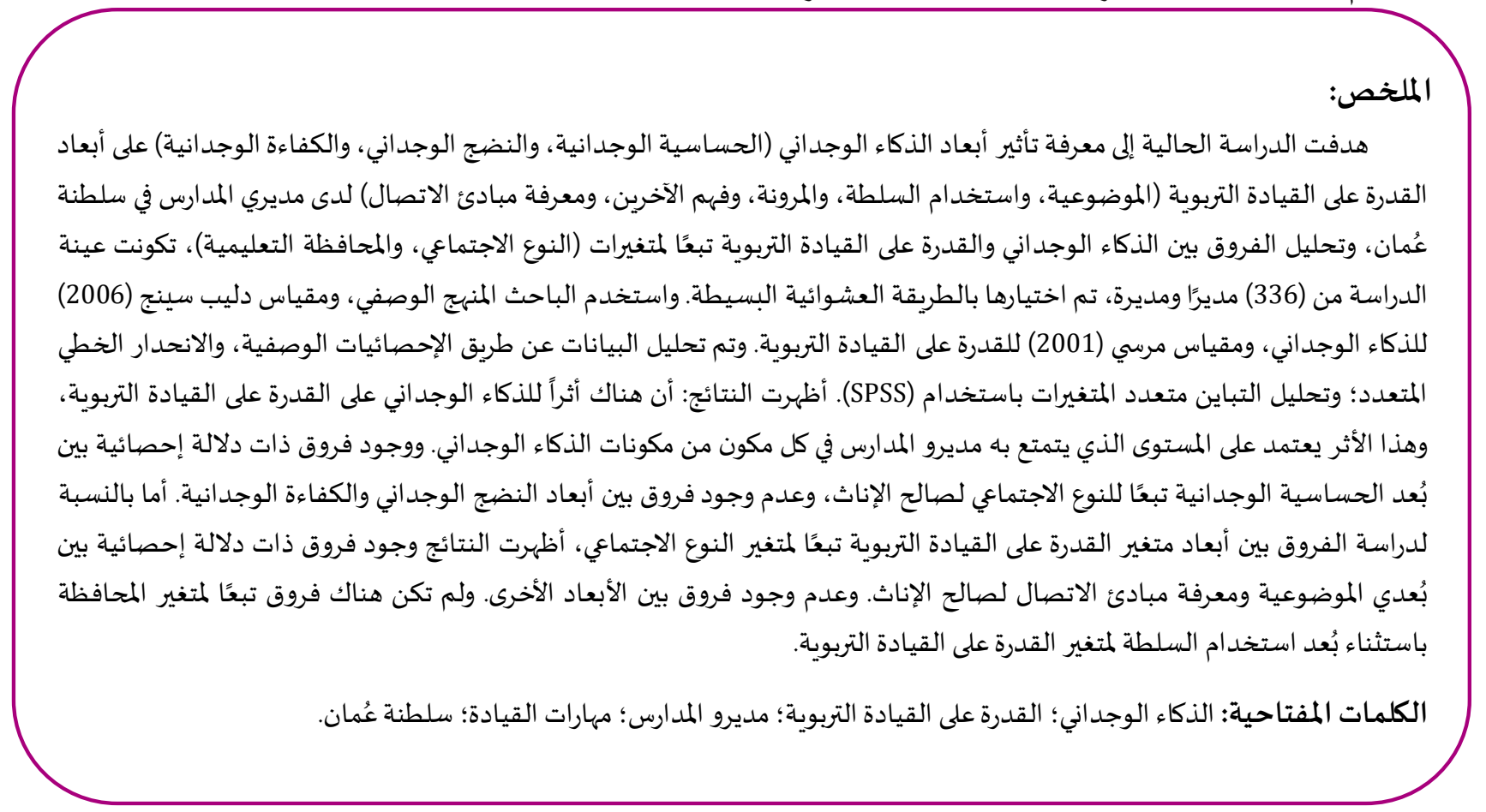

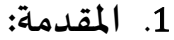

يُعد السلوك القيادي للمدير، مفتاح نجاح المؤسسة التعليمية، وأن الاختلاف والتباين بين المدارس سواء في المناخ المدرسي العام، أو تحصيل

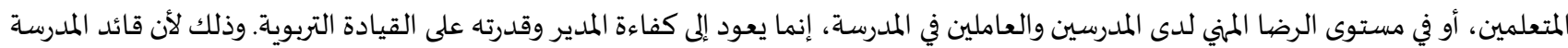

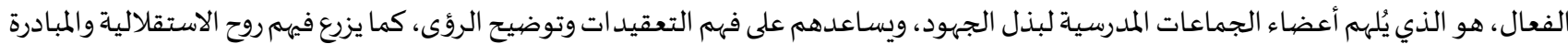

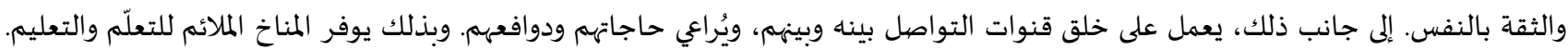

(Maulod et al., 2017)

وفي العصر الحالي يتطلب من مديري المدارس مهارات تتجاوز مجرد الإشراف على التدريس والمناهج الدراسية، بل عليهم أيضًا توفير بيئة آمنة

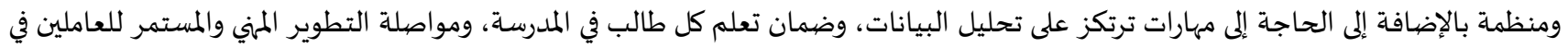

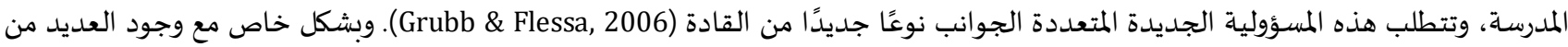

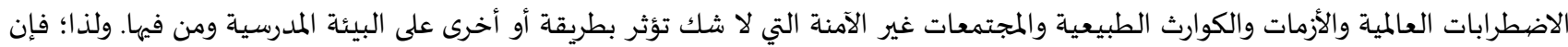

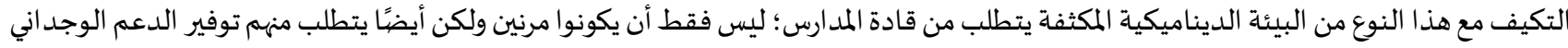


لأعضاء هيئة التدريس (Bumphus, 2008). ونتيجة لذلك، أصبح دور مديري المدارس نحو قيادة المدرسة للنجاح أكثر تعقيدًا ومتعدد الأوجه، حيث يجب أن يكونوا مديرو المدارس قادرين على رعاية وتشجيع ودعم التعلم في مواجهة التغيرات السريعة المعقدة (Bullan, 2007).

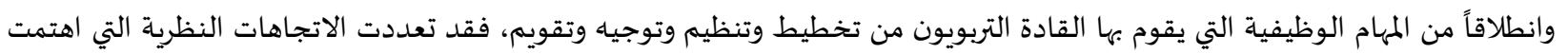

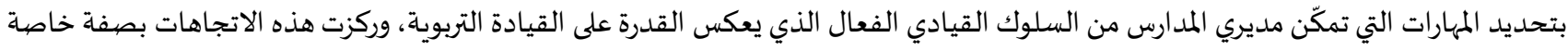
على المهارات ذات العلاقة المباشرة بالبعد الإنساني في العمل (Oluremi, 2008). كما أن هناك عددًا من الدراسات المات المبكرة أشـارت إلى أن العلاقات

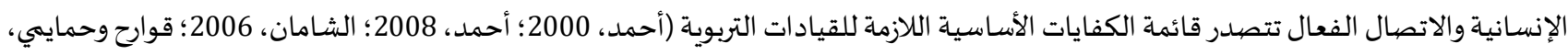

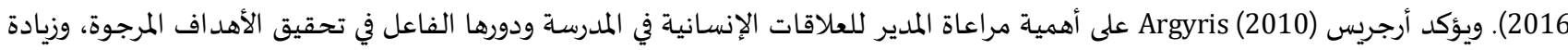

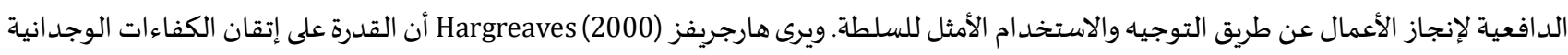

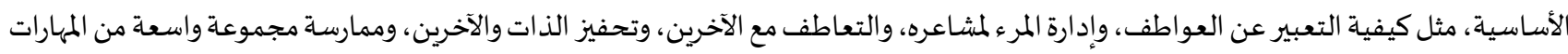

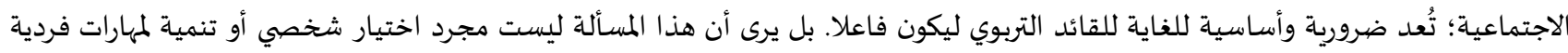

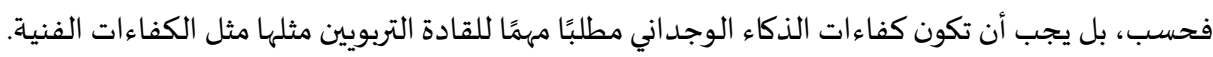
ويُعد الذكاء الوجداني وقدرة المدير على القيادة التربوية عنصيرين مهمين في تحديد نجاح المدرسة، على اعتبار أنهما من أهم المتطلبات التي تمكّن

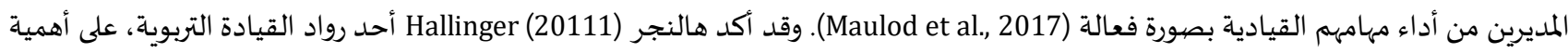
الدراسات المتعلقة بالقيادة التربوية في خلق مدارس فعالة مهادية وأن مهارات معرفة الذات ومعرفة الآخرين تساعد في تنمية وتطوير فاعلية المديرين كقادة

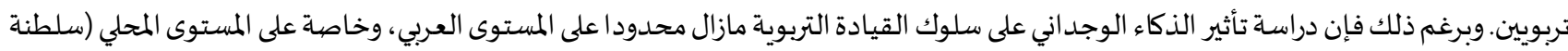

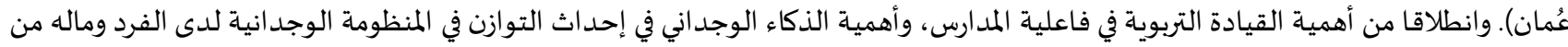

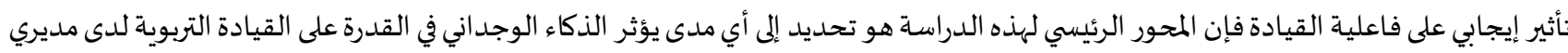
المدارس بسلطنة عُمان؟

1.1 1 - 1 مشكلة الدراسة:

في مراجعة للدراسـات التجريبية حول القادة التربويين والعواطف التي نشرت بين عامي 1992و و2012 في مجلات القيادة التربوية المحكّمة، ومجلات

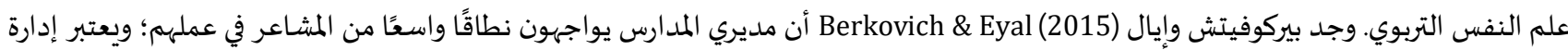

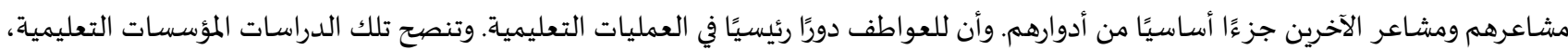

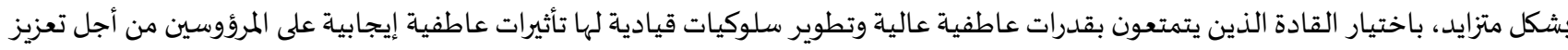

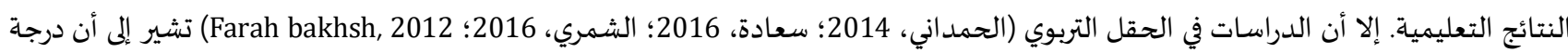

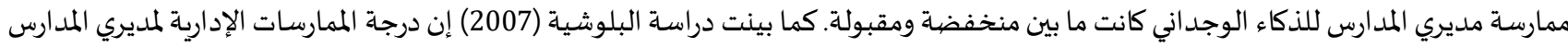

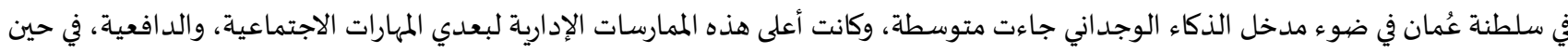
إن الممارسات الإدارية المتعلقة بتنظيم الذات، والتعاطف، والوعي الذاتي كانت ضعيفة. وفي الجانب الآخر أشارت عدد من الدراسات (حبيشي، 2012؛

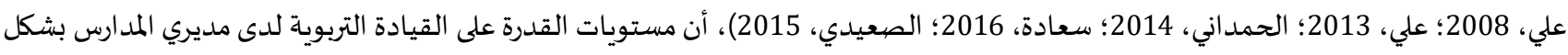

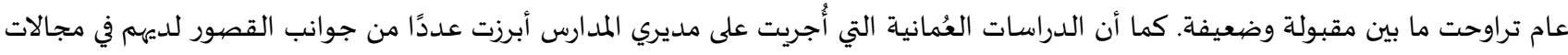

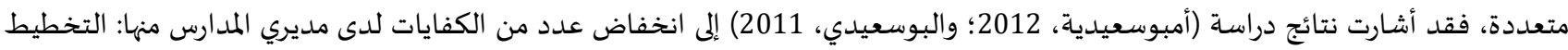

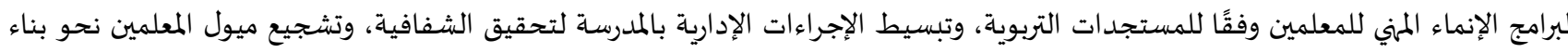

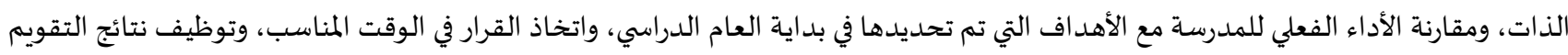

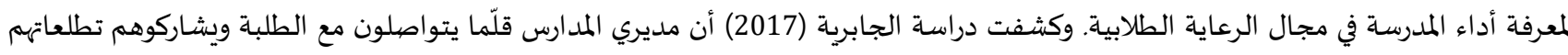

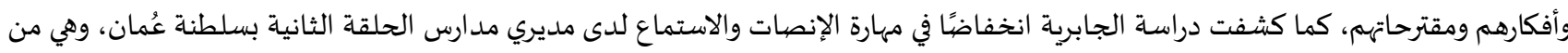

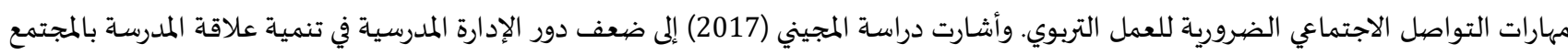

وقاعدة البحث حول الذكاء الوجداني وعلاقته بالقيادة التربوية لا تزال في مراحلها الأولى على الرغم من أن الحقل التربوي من أهم حقول المجتمع ألما

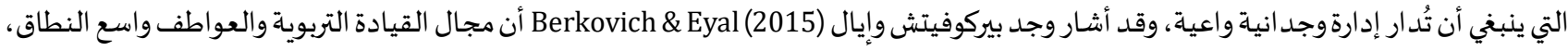

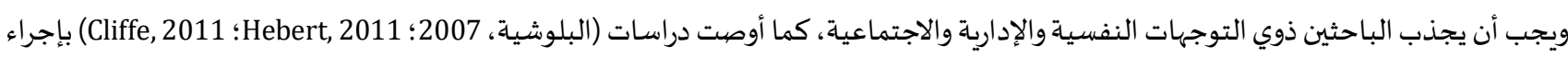

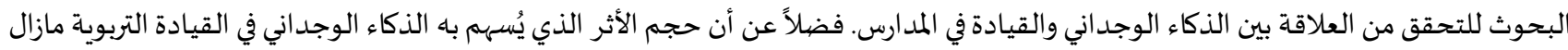

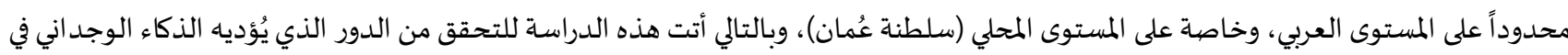

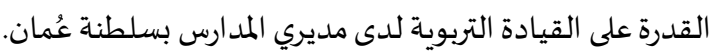


2.1 2.1 أسئلة الدراسة:

تُجيب هذه الدراسة على التسـاؤلات التالية:

1. ما تأثير أبعاد الذكاء الوجداني (الحساسية الوجدانية،، والنضجج الوجداني، والكفاءة الوجدانية) في مهارات القدرة على القيادة التربوية (الموضوعية،

واستخد ام السلطة، والمرونة، وفهم الآخرين، ومعرفة مبادئ الاتصال) لدى مديري ومديرات المدارس بسلطنة عُمان؟

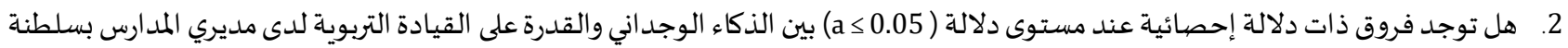

عُمان تبعًا لمتغيرات (النوع الاجتماعي، والمحافظة التعليمية)؟

3.1 أهداف الدراسـة:

تهدف هذه الدراسة إلى تحقيق الأهداف العلمية التالية:

1. معرفة تأثير أبعاد الذكاء الوجداني (الحساسية الوجدانية، والنضج الوجداني، والكفاءة الوجدانية) على أبعاد القدرة على القيادة التربوية

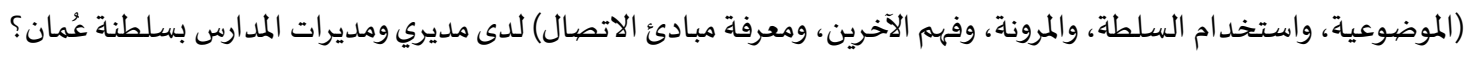

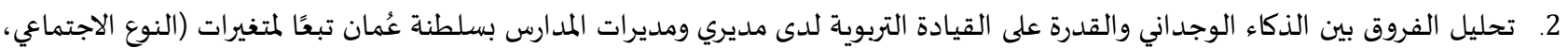

والمحافظة التعليمية)؟

4.1 أهمية الدراسـة: - 4.1

• الأهمية النظرية: تتجسد الأهمية النظرية للدراسة من خلال عدة نقاط جوهرية؛ أولها دور المدرسة كوحدة تطوير أساسية لإصلاح التعليم، وتربية

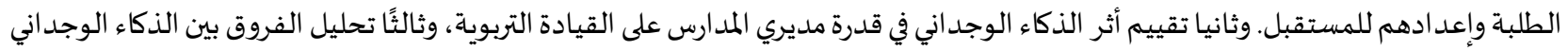

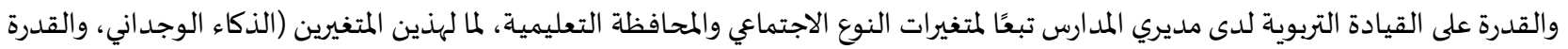

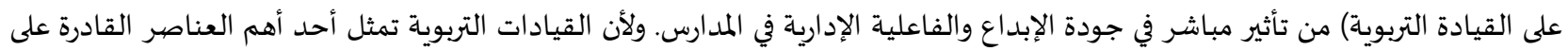

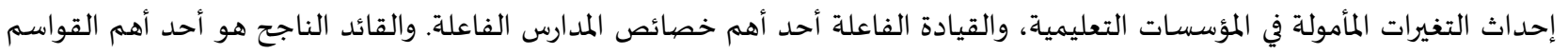
المشتركة للمدارس الفاعلة (Sammons,1999). فضلا عن النقاط سالفة الذكر، فإن ندرة مثل هذه الدراسـات في البيئة العربية بشكل عام والمات والبيئة

العُمانية بشكل خاص -حد علم الباحث- تدعونا لأهمية تناول العلاقة بين الذكاء الوجداني والقدرة على القيادة التربوية لدى مديري المدارس. الأهمية التطبيقية: تتمثل الأهمية التطبيقية للدراسة في تنمية اتجاه جديد بدأ ينمو في الآونة المتأخرة في مجال بحوث السلوك التنظيمي وإدارة

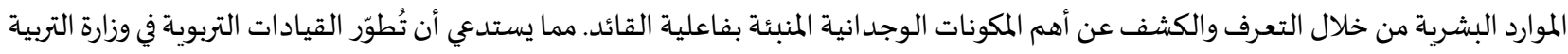
والتعليم من أسس اختيار أو تعيين مديري المدارس، بحيث يؤخذ في الحسبان جانب الذكاء الوجداني عند عملية الاختيار. كما تتجسد الأهمية

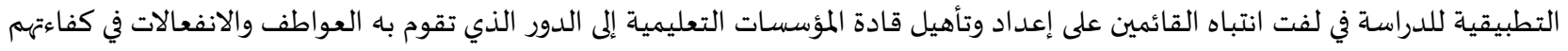

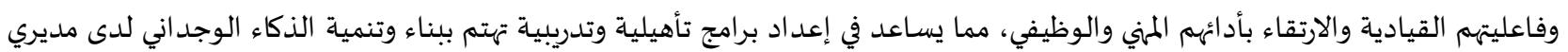
ومديرات المدارس عن طريق برامج التأهيل في كليات التربية، أو برامج التدريب أثناء الخدماءئ.

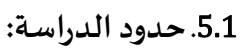

الحدود الزمانية: جرى تطبيق هذه الدراسة في الفصل الثاني من العام الدراسي 2019 / 2020م. • الحدود المكانية: طُبقت هذه الدراسـة في تسع محافظات تعليمية بسلطنة عُمدان. المحددد البشري: طبقت هذه الدراسة على مديري ومديرات المدارس بسلطنة عُمان. الحدود الموضهوعية: تتحدد هذه الدراسة بتحليل العلاقة بين الذكاء الوجداني والقدرة على القيادة التربوية لدى مديري ومديرات المدارس بسلطنسة

الذكاء الوجداني: Emotional Intelligence بناء على تعريف داليب سينغ (Singh, 2006) للذكاء الوجداني يمكن أن نعرّف القائد الذكي وجدانياً بأنه: القائد الذي لديا القدرة على الاستجابة الملائمة والناجحة لمجموعة واسعة من المثيرات العاطفية التي تستمد من داخل النفس والبيئة المحيطة

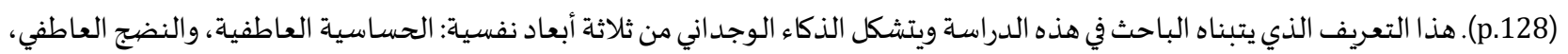
والكفاءة العاطفية، والتي تدفع الفرد إلى التعرف على ديناميات السلوك البشري، وتفسيره بأمانة وتناوله بلباقة. ويُعرّف الذكاء الوجداني إندادئ إجرائياً

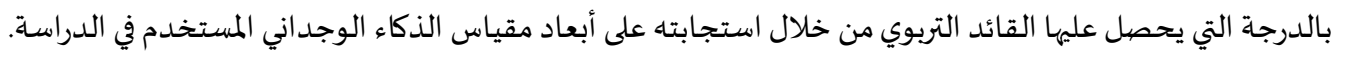
القيادة التربوية: Educational Leadership يقصد بالقيادة التربوية مدى تمكّن القائد التربوي من امتلاك القدرات القيادية التي تساعده على

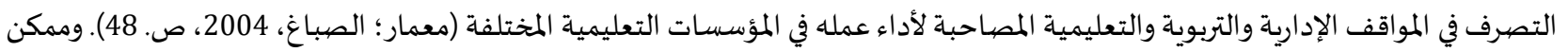


القول إن القيادة التربوية: هي القدرة على دعم وتفعيل العمل الجماعي، وتسعى إلى تحسين ثقافة المؤسسة، ورفع قدرات الأفراد، وتجويد المخرجات

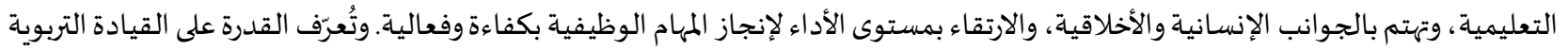
إجرائيا في هذه الدراسة بأنها الدرجة الكلية التي يحصل عليها القائد التربوي من خلال استجابته على أبعاد مقياس القدرة على القيادة التربوية المعد

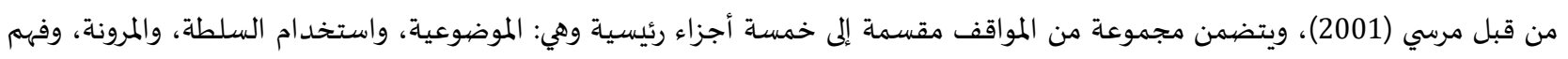
الآخرين، ومعرفة مبادئ الاتصال.

مدير المدرسـة: Headmaster هو القائد التربوي الذي يقوم بإدارة العملية التعليمية التعلّمية بالمدرسة وتسهيل كافة متطلباتها التنظيمية والتنفيذية

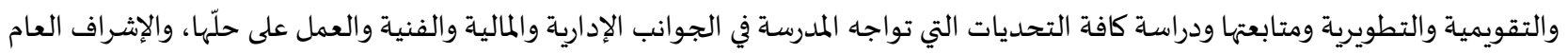

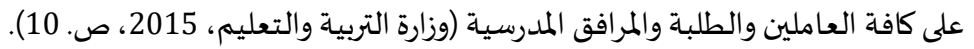

\section{2. القيادة التربوية ومهاراتها الرئيسية:}

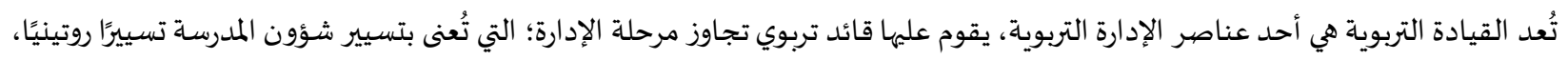

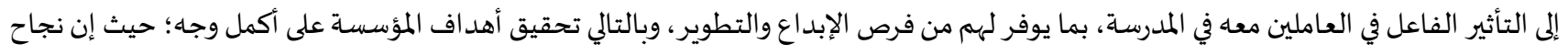
المؤسسة التربوية في تحقيق أهدافها يعتمد على قدرات القائد التربوي، وخصيائصها وإمكاناته في توجيه العمل، ورعاية العاملين معاه، وتقديم العون

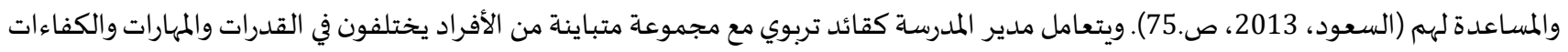
والميول والدوافع والاتجاهات وطرائق التفكير وأساليب التعامل، ولذلك فهو بحاجة إلى مجموعة من المهارات الرئيسية للقيادة التربوية يستخدم فيها أساليب مختلفة للتعامل مع هؤلاء الأفراد. ويؤكد دارسو القيادة التربوية والمشتغلون مؤهرة ببحوثها أن القدرة على القيادة التربوية تتكون من خمس مهارات رئيسية، كل مهارة منها تقيس جانبًا من

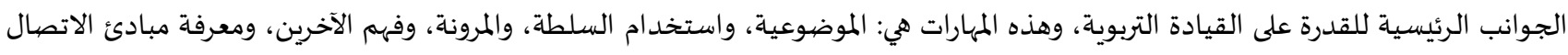

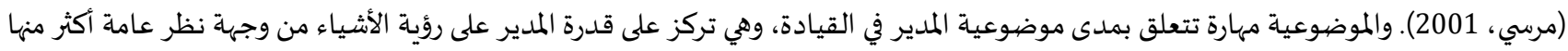

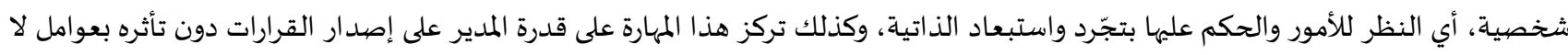

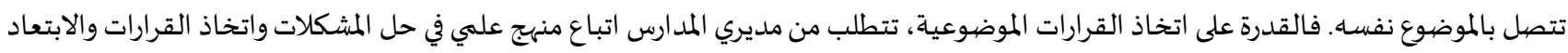

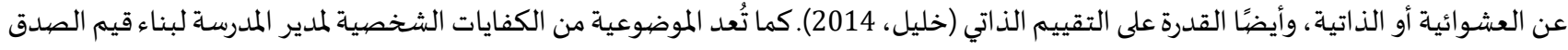

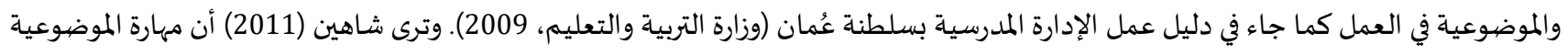

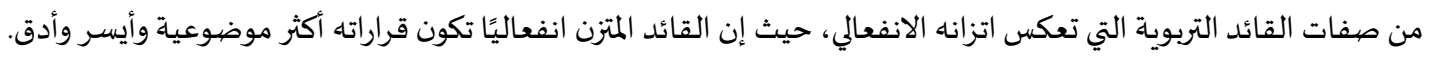

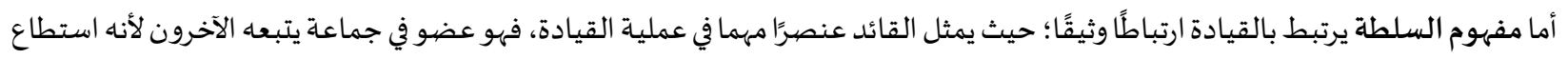

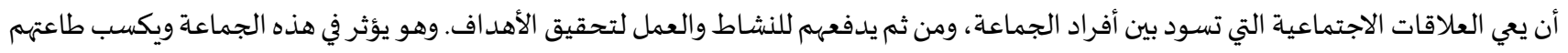

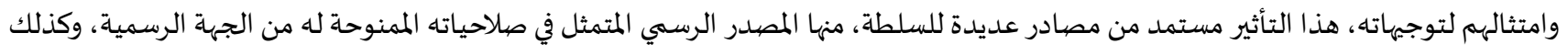

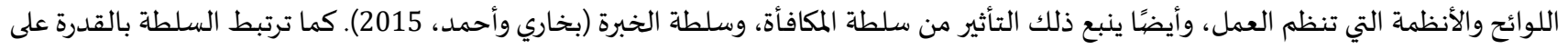

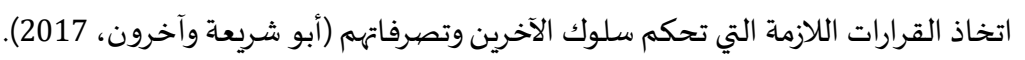
ويرى مرسي (2001) أن هناك عدة صهور أو أشكال للسلطة منها: سلطة القانون، وسلطة المعرفة والعلم، وسلطة العرف والتقاليد، ثم سلطة الميول

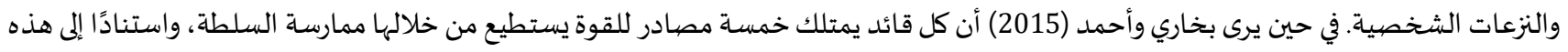

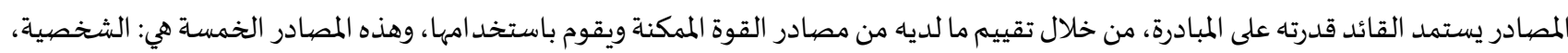
والعلاقات والمنصب والمعرفة وأخيرا المهمة.

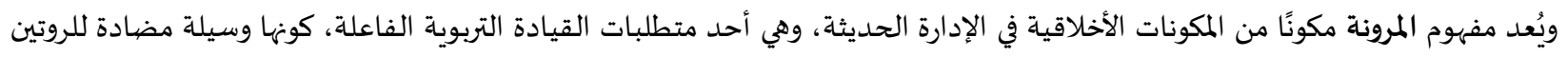

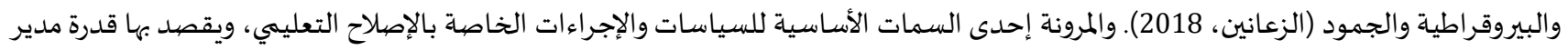

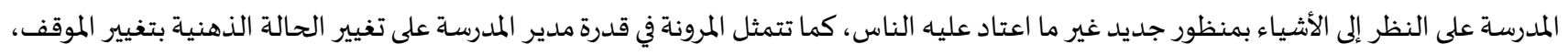
وتعكس المرونة الإدارية حنكة القائد التربوية وقدرته على توظيف الظروف المحيطة لتحقيق أهداف المدرسة (العنزي، 2017).ومدير المدير المدرسة الذي يتسم

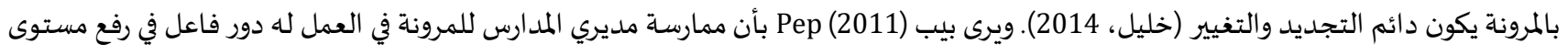

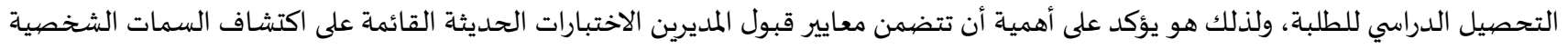

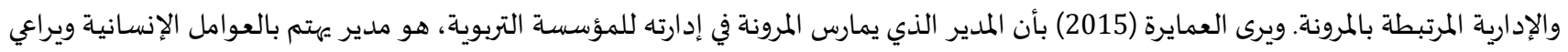

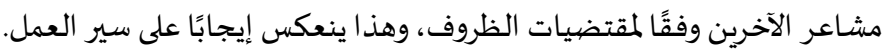


وتعكس مهارة فهم الآخرين مدى قدرة المدير على فهم ديناميات الجماعة والدوافع التي تحركها وتحكمها؛ وكذلك قدرته على فهم أفكار الآخرين

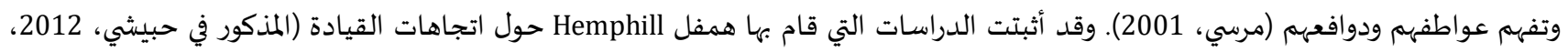
ص.155) بأن ما يميز القائد المؤثر من القائد غير المؤثر هو أن الأول يعنى بأحاسيس ومشكاتلات المجموعة التي يعمل معها. كما تُعتبر التشاركية من المبادئ

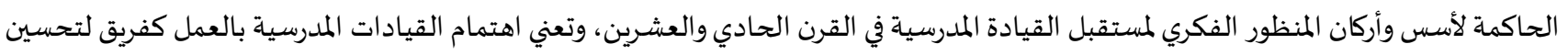
المدرساة، من خلال إدراك احتياجات العاملين، والاعتراف بإسهاماتهم وتشجيعهم على إنجاز مهامهم، مما يضمن تنامي الإنجاز ويجعل البيئة المدرسية

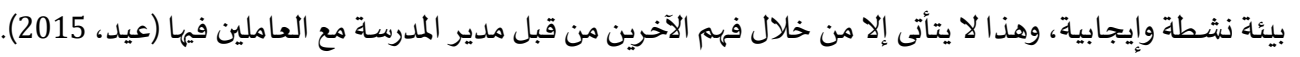

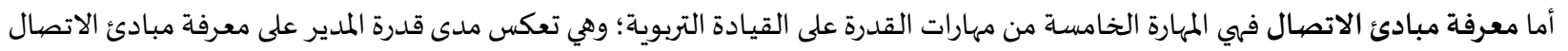

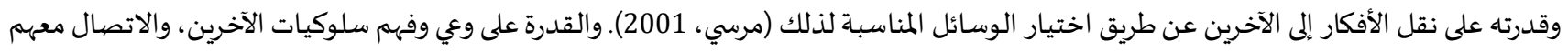

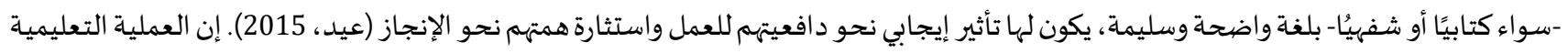

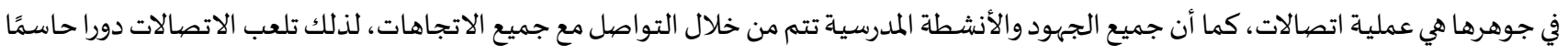

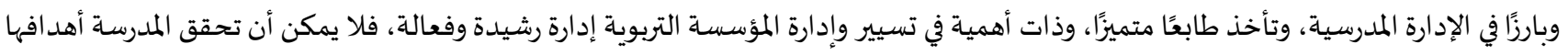

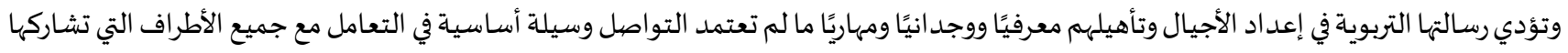

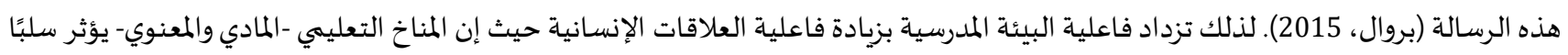

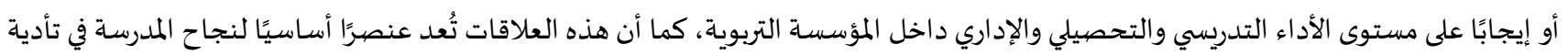

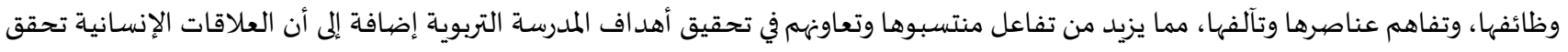

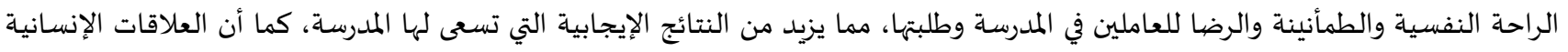

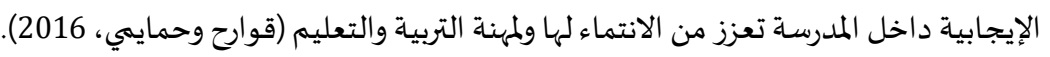

2.2. تأثير أبعاد الذكاء الوجداني على القيادة التربوية:

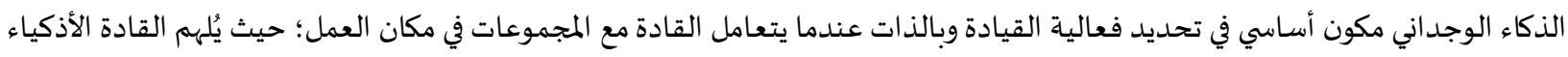
وجدانيًا أعضاء فرق العمل بكفاءة من أجل تحقيق الهدف التنظيمي (Srivastava, 2013).وتُعتبر القيادة الفعالة منذ أمد بعيد حيوية فيما يتعلق بالأداء

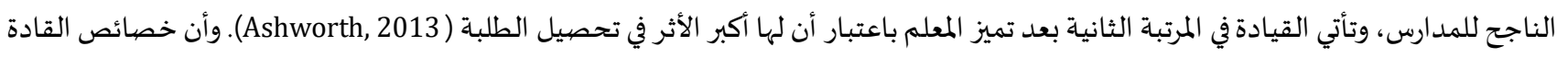

تنعكس بشكل واضح في قياس الثقافة المدرسياة، وفعالية المعلمين ومعنوياتهم، ويكون لها تأثير على تحصيل الطلبة (Maulding et al., 2012, p. 4).

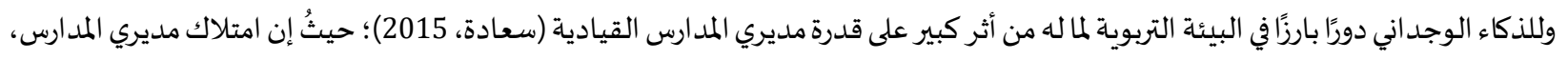

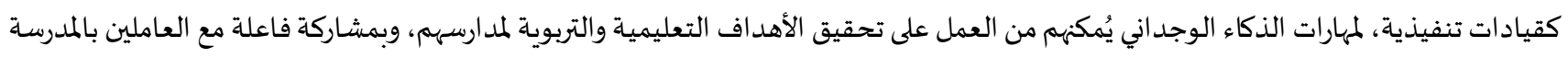

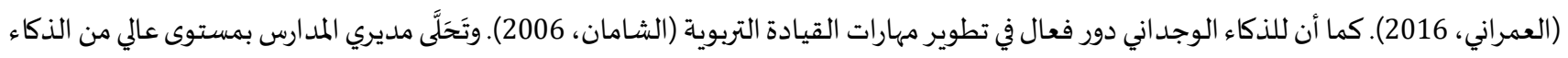

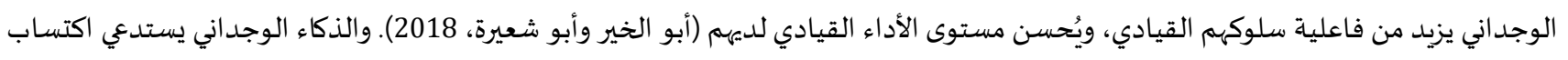

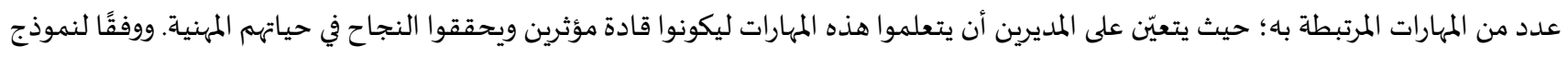

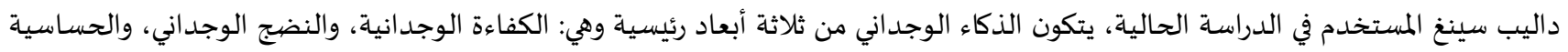

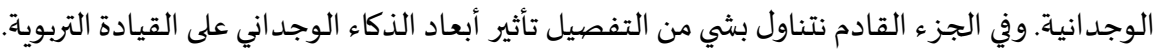

أولاً: القدرة على القيادة التربوية والكفاءة الوجدانية (Emotional Competency):

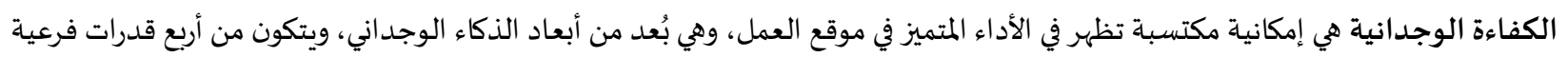

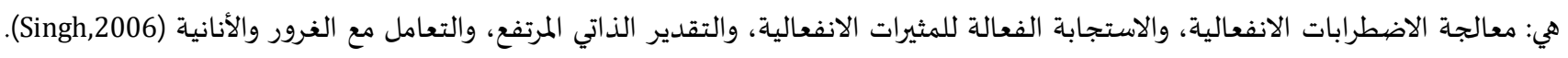

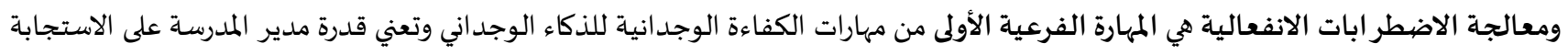
بلباقة إلى المثير الانفعالي الذي تحركه مواقف متنوعة كالإحباطات مختلفة الأسباب، ومواقف الصراع التي تسبب إثارة انفعالية، والشعور بعقدة الثبات النقص.

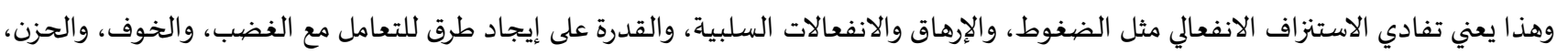

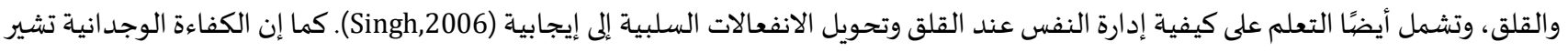

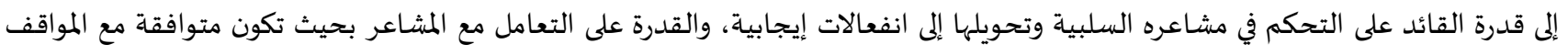

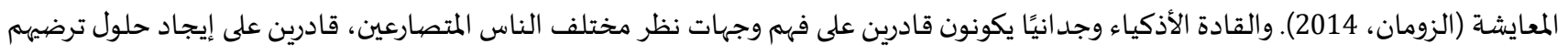
أو على الأقل أرضية مقبولة منهم ليس ذلك فحسب بل أيضًا توجياه المتصارعين للاتفاق حول رؤية مستقبلية أفضل يسعون إلى تحقيقها (

(al., 2002

أما المهارة الثانية في هذا البُعد هي الاستجابة الفعالة للمثيرات الانفعالية: وتعني أن يتفاعل مدير المدرسة إيجابيا تجاه المطالب الوجدانية

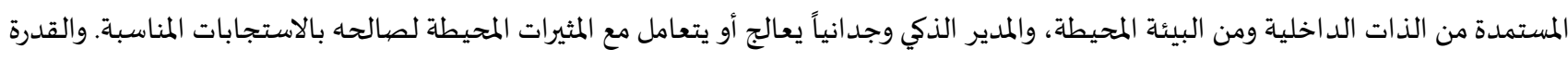


على تنظيم العواطف هي سمة إيجابية ترتبط بالأداء الإيجابي في مكان العمل وإن القادة الفاعلين قادرون على إدارة عواطفهم، ونتيجة لذلك فإن الموظفين

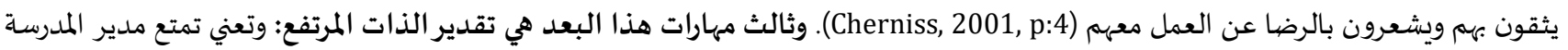

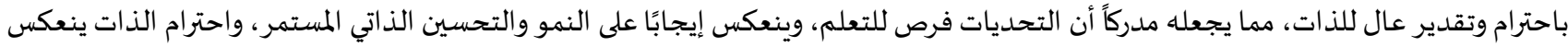

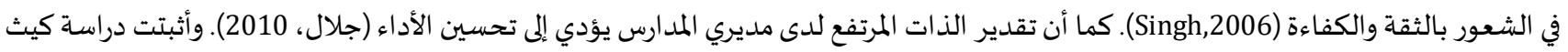
(2009) Keith بأن هناك علاقة إيجابية بين الذكاء الوجداني والقيادة الفعالة لدى مديري المدارس؛ حيث تؤثر مهارة الثقة بالنفس وهي من مهارات الذكاء

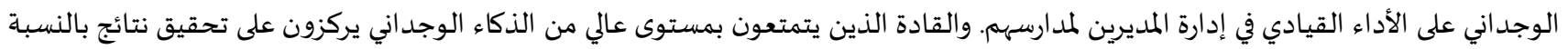

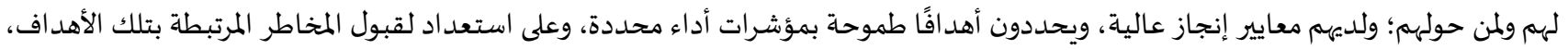

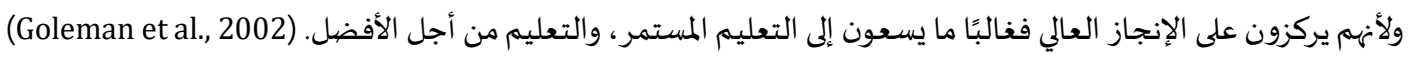

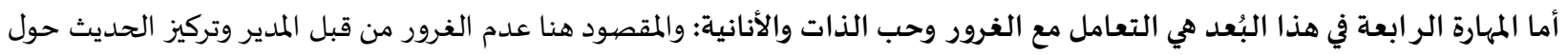

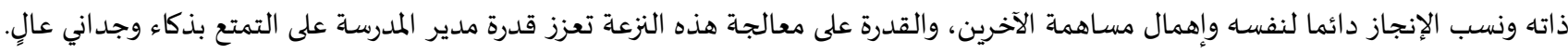

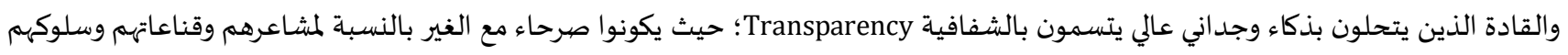

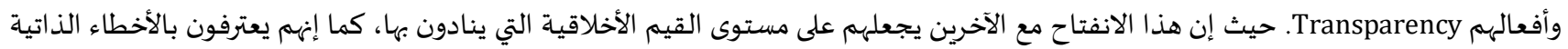

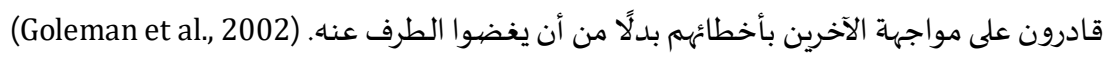

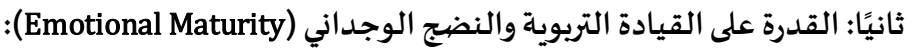

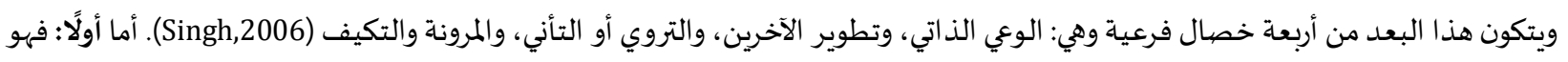

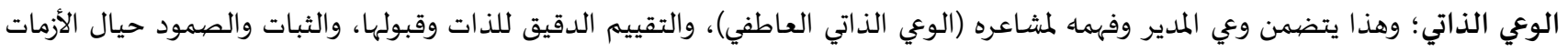

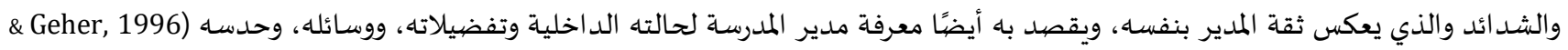

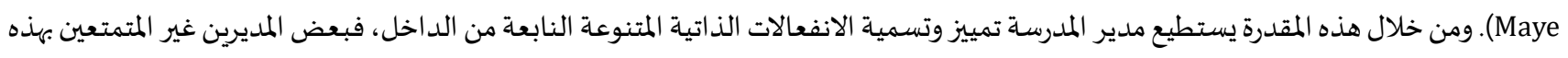

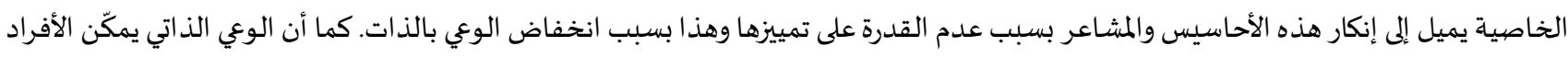

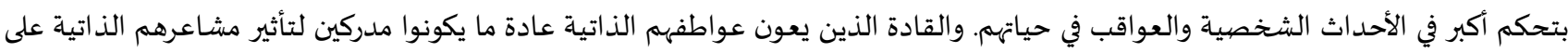

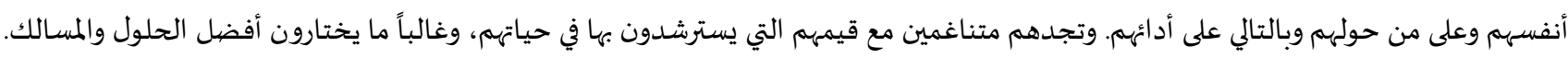
ويكونوا صرحاء وصادقين مع أنفسهم، ومع الآخرين، قادرين على التحدث بوضوح عن عن مشاعرهم وعواطفهم ورؤيتهم للأمور (Goleman et al., 2002).

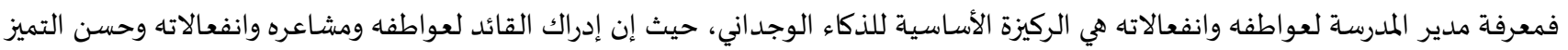

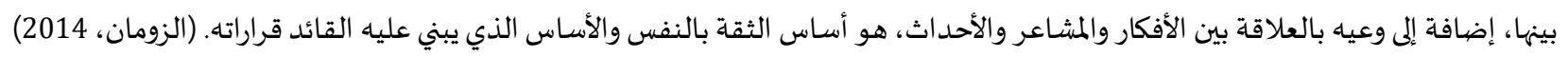

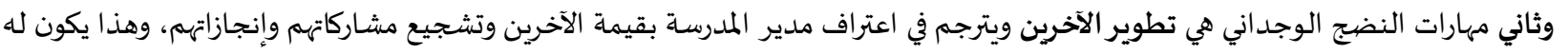

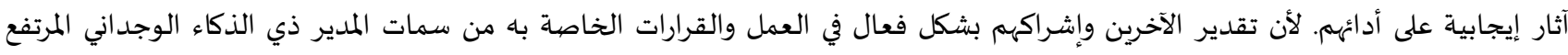

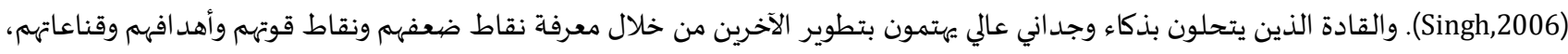

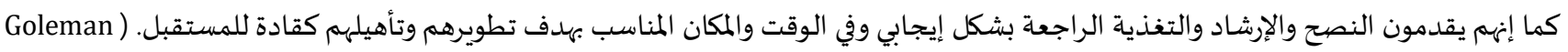
(et al., 2002

أما المهارة الثالثة في هذا البعد هي التروي: والمقصود هنا تأني مدير المدرسة في الحكم على الأشياء وعدم التسرع وتجنب رد الفعل السريع، مما

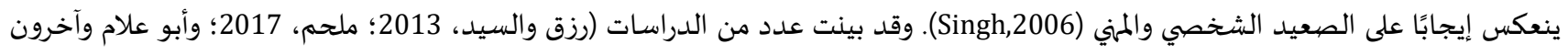

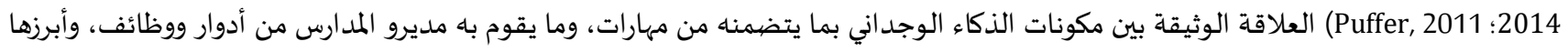

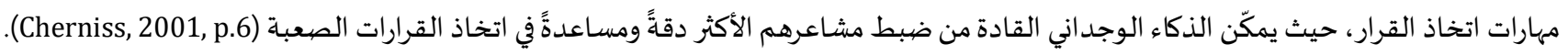

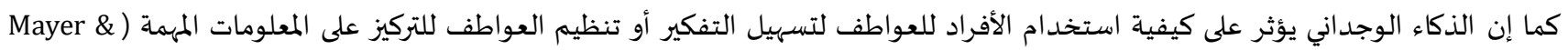

.(Salovey, 1997

والمهارة الرابعة في هذا البعد هي المرونة والتكيَف، وتعني معرفة كيف ومتى يأخذ مدير المدرسة زمام المبادرة ومتى يتبع الآخرين. وهذه المهارة من

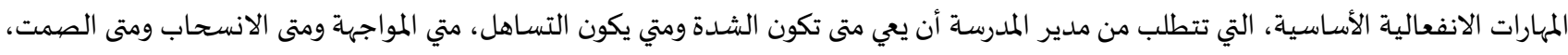

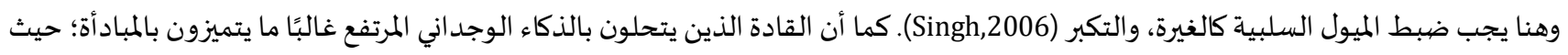

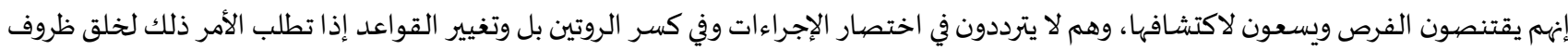
أفضل. (Goleman et al., 2002) 
ثالثًا: القدرة على القيادة التربوية والحساسية الوجدانية (Emotional Sensitivity):

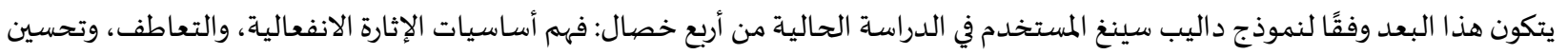
العلاقات مع الآخرين، والتواصل الوجداني الفعال (Singh,2006). أن مراعاة الاحتياجات العاطفية للموظفين من قبل القائد هو المفتاح لتحقيق أقصى

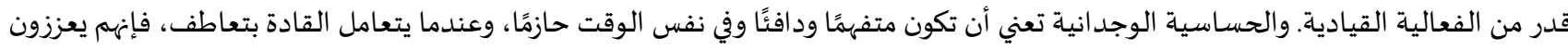
الثقة مع الموظفين ويسمحون لهم بتحمل المسؤولية عن أفعالهم وأعمالهم، والقادة الحساسون يتعاطفون مع الآخرين، والحساسية كبُعد من أبعاد

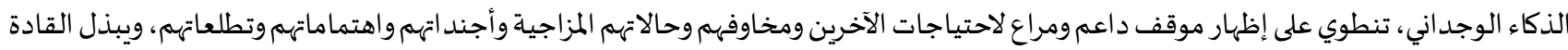

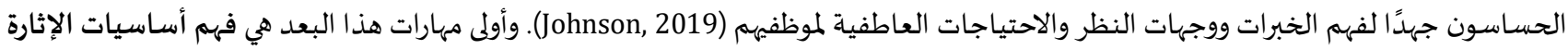

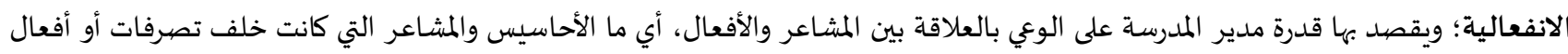

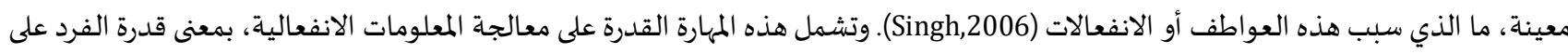

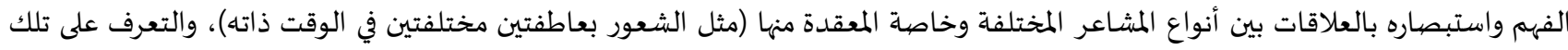
الانفعالات التي تؤثر على عمليات التفكير (Mayer \& Salovey, 1997).

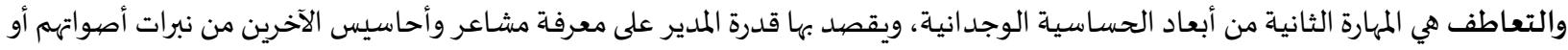

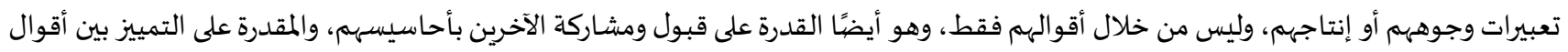
وأفعال الآخرين أي التمتع بالبصيرة في كيفية تقييم الآخرين. كذلك التعاطف هو توفير الشعور بالراحة للآخرين في الصحبة، كذلك الأمانة في التعاملات

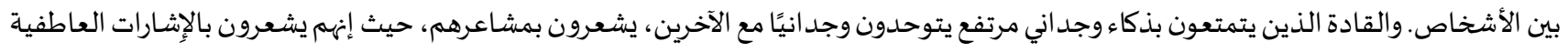

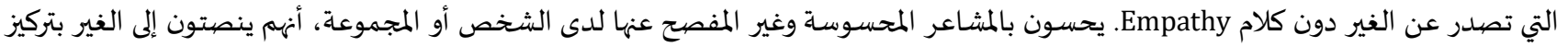

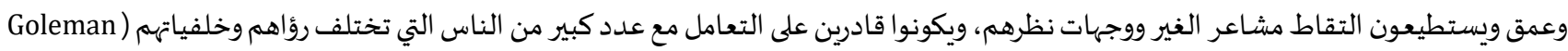

(et al., 2002

أما تحسين العلاقة بالآخرين؛ فهي المهارة الفرعية الثالثة في بُعد الحساسية الوجدانية وتأتي هذه القدرة لتوثيق العلاقة بالآخرين، وتتعزز من خلال

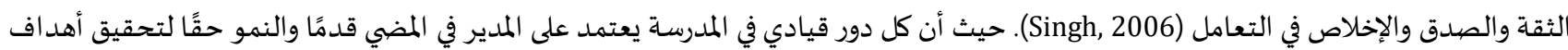
المدرسة بأكملها؛ وبالتالي على مدير المدرسة (كقائد) أن يركز على الطبيعة التآزرية المشتركة لقيادة المدرساة، وهذا لا يتأتى إلا إذا أهتم المدير بالآخرين

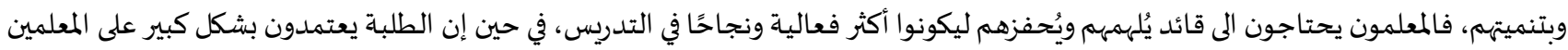
في اكتساب المعرفة والمهارات، ولذلك فنجاح وفعالية تأثير أي مدرسة يعتمد بشكل كبير على قيادة المدير (Mak, 2014 ). كما أن تحلي مديري المدارس

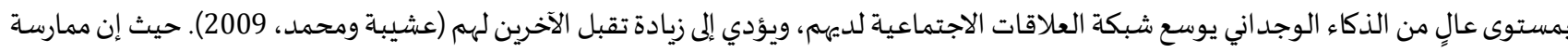
العلاقات الإنسانية الفعالة مع الآخرين من قبل مديري المدارس كمهارة من مهارات الذكاء الوجداني تؤثر إيجابيًا على مستوى ممارستهم لصنع القرار

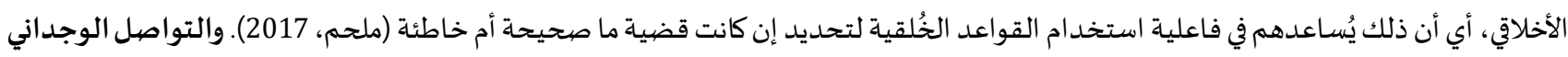

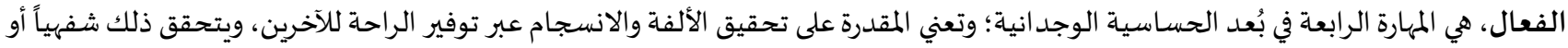

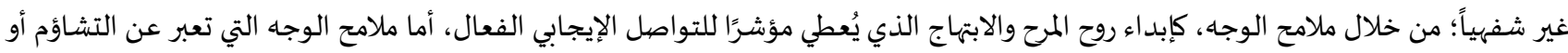

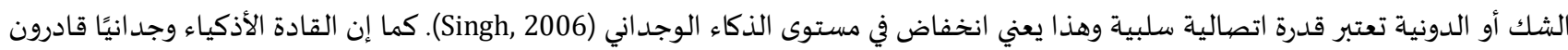
على إلهام الأخرين والتأثير فيهم Inspiration، من خلال صياغة رؤية مشتركة عن وضع أمثل في المستقبل وجعل الغير يعتنقها ويعمل من أجلها.

(Goleman et al., 2002)

3.2. تأثير النوع الاجتماعي على الذكاء الوجداني والقدرة على القيادة التربوية:

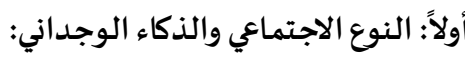

أظهرت الأبحاث حول الفروق الفردية اهتمامًا كبيرًا بتأثير القدرات الوجدانية كمصادر شخصية للأفراد. ومن بين القدرات الوجدانية، يُعد الذكاء

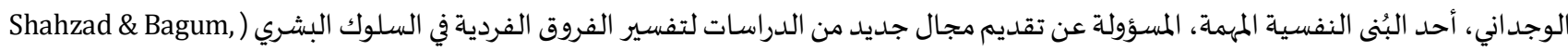

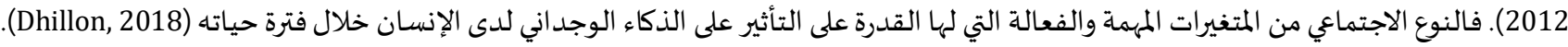

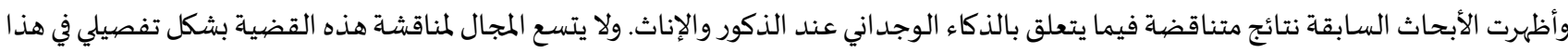

ولأن أحد أهداف الدراسة الحالية تحديد إمكانية وجود اختلافات بين الجنسين على متغير الذكاء الوجداني في إطارنا الثقافي التربوي من خلال

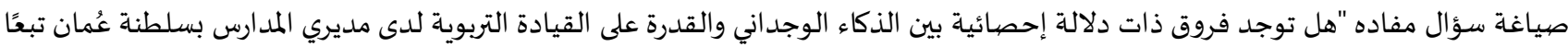

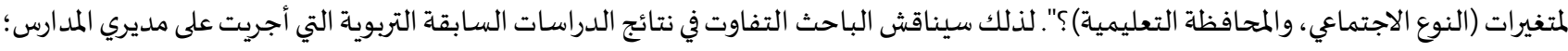
حيث بينت نتائج عدد من الدراسات السابقة إلى أن مستوى الذكاء الوجداني لدى مديري المدارس لا يتأثر بالنوع الاجتماعي (أبو الخير وأبو شعيرة، 2018؛ 
البلوشية، 2007؛ الحراحشة، 2013؛ سعادة، 2016؛ العفنان، 2011؛ صبيرة، وتفاحة، 2016؛ المغاري، 2018؛ Gutierrez )، في حين أشارت 2017

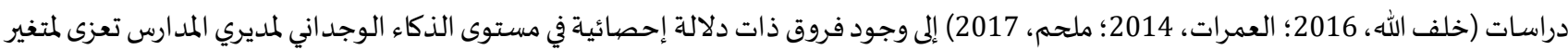
النوع الاجتماعي ولصالح الذكور. في الجانب الآخر أشارت دراسة الهنداسي (2008) إلى عدم وجود فروق ذات داتلاتلة في بعد الوعي بالذات، ووجود فروات فروق

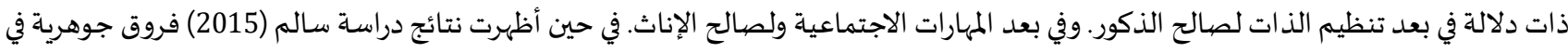
الدرجة الكلية للذكاء الوجداني ومجالاته (الوعي الذاتي، والتعاطف، والمهارات الاجتماعية) لدى مديري المدارس تعزى للنوع الاجتماعي وكانت لصالح

وقد يكون التباين في مستويات الذكاء الوجداني لدى كل من الذكور والإناث في نتائج الدراسـات السابقة سببـ اختلاف المقاييس المستخدمة في تلك الد ارسات، وكذلك اختلاف عيناتها فبعض تلك الدراسات استهدفت مديري المدارس أنفسهم كدراسات (علي، 2013؛ العمرات، 2014؛ سعات إتهادة، 2016؛

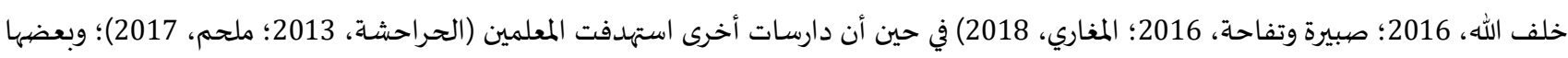
تكونت عيناتها من مديري مدارس ومعلمين كدراسة سالم (2014)، في حين تكونت عينت دراسة أبو الخير وأبو شعيرة (2018) من المشرفين التربويين.

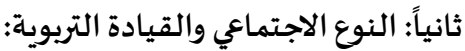

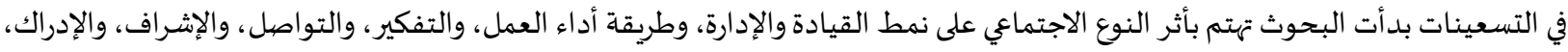

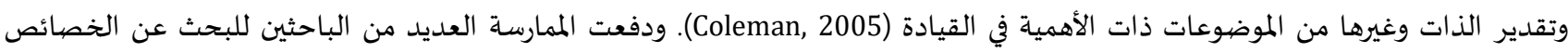

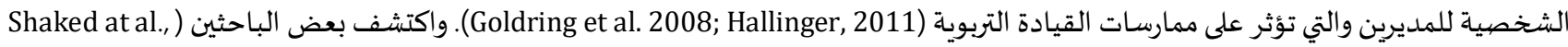
2018; Kis and Konan 2014; Krüger 2008; Shanmugam et al., 2007 التربوية. ومعرفة العلاقة بين النوع الاجتماعي وأسلوب القيادة وافترضوا أن النوع الاجتماعي هو سمة شخصية مهمة تؤثر على أسلوب أو نمط القيادة

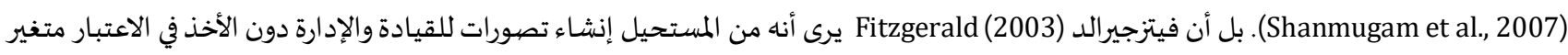

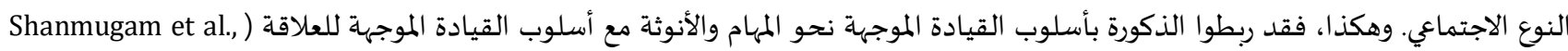

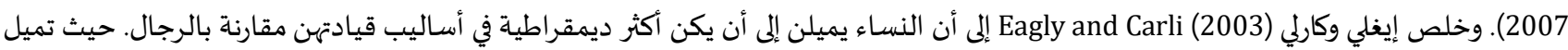
الإناث إلى أسلوب القيادة الأكثر رعاية والموجهة نحو العلاقيات، بيناتينما يُظهر الرجال أسلوب قيادة أكثر استبدادية (Eagly and Johnson, 1990). وتتبنى المديرات أساليب قيادة أكثر تشاركية وديمقراطية ومركزة على المهام من نظرائهن الذكور. (Eagly et al., 1992)

4.2 - 4.2 الدراسات السـابقة:

ركزت دراسة مالدينج وآخرون (2012) .Maulding et al على الذكاء الوجداني والمرونة كمنبئين للقيادة لدى مديري المدارس. تم إجراء هذه الدراسة باستخدام المنهج (الكمي، والنوعي) على (48) من مديري المدارس من ثلاث ولايات في جنوب شروق المات الولايات المتحدة. واستخدم استبانة

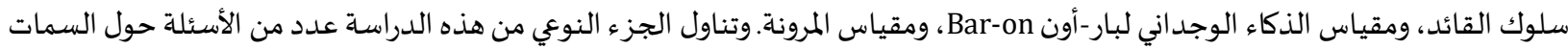

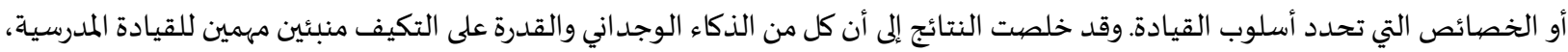

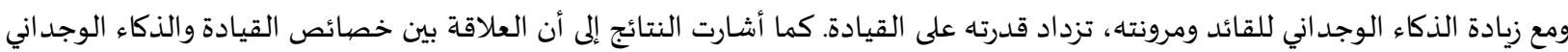
والمرونة كبيرة. وهدفت دراسة رذق والسيد (2013) إلى الكشف عن واقع مكونات الذكاء الوجداني وعلاقتها بمهارات اتخاذ القرار لدى مديري مدارس التعليم

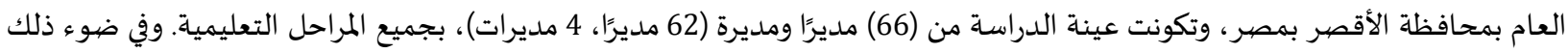

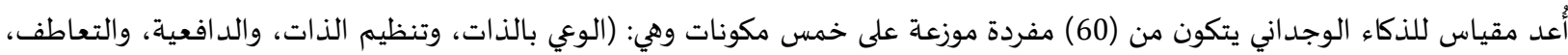

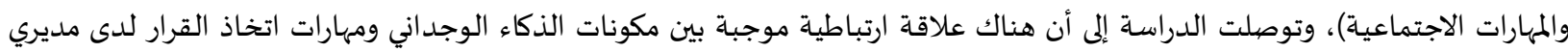

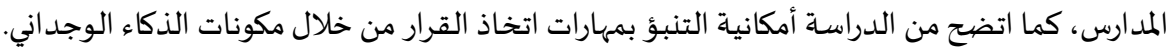
وهدفت دراسة علي (2013) إلى معرفة درجة ممارسة القيادة التربوية لدى مديري المدارس الابتدائية والإعدادية بمحافظة الدقهلية وعلاقتها

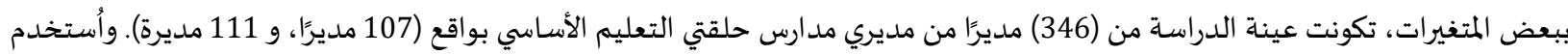

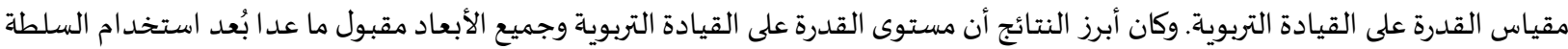

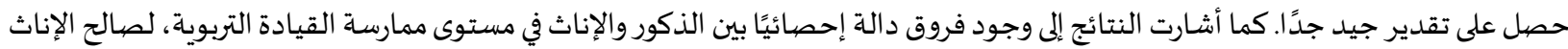

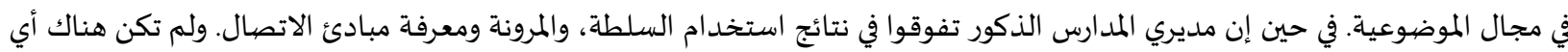
فروق ذات دالة إحصائية في مجال فهم الآخرين. وهدفت دراسـة العمرات (2014) إلى التعرف على مستوى الذكاء الوجد اني وعلاقته بفاعلية القائد لدى مديري مد ارس البتراء وتربية وادي السير

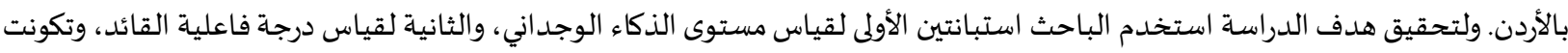

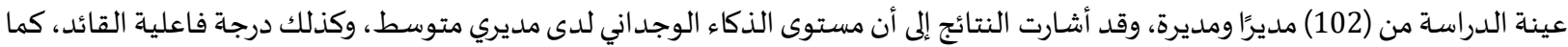


أشارت النتائج إلى وجود فروق ذات دلالة في مستوى الذكاء الوجداني تعزى لمتغير النوع الاجتماعي ولصالح الذكور، وأشارت النتائج إلى وجود علاقة

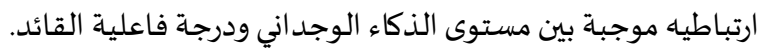
وهدفت دراسة هانلين Hanlin لتحديد ما إذا كانت هناك علاقة بين الذكاء الوجداني وممارسات القيادة المدرسية الفعالة لمديري المدارس،

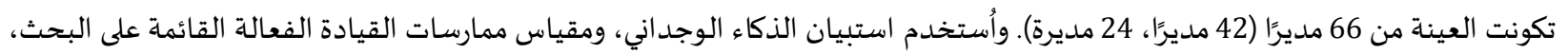

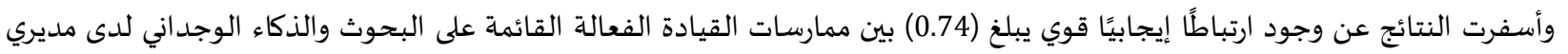

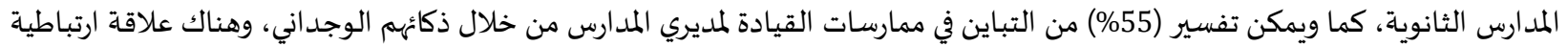

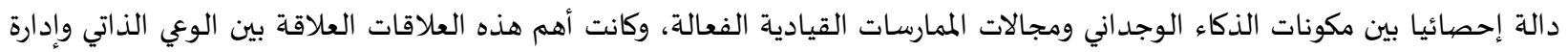

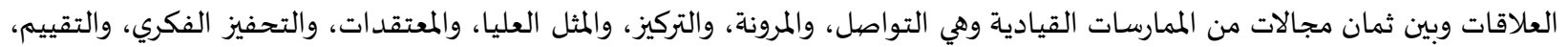
والتوعية. وهدفت دراسة سالم (2015) إلى التعرف على طبيعة العلاقة بين الذكاء الوجداني لمديري مدارس المرحلة الثانوية والولاء التماء التنظيمي للمعلمين بغزة.

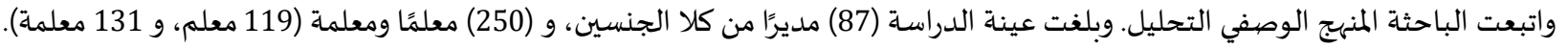

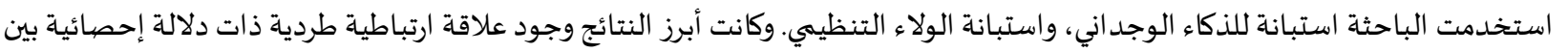

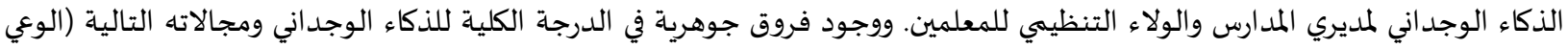

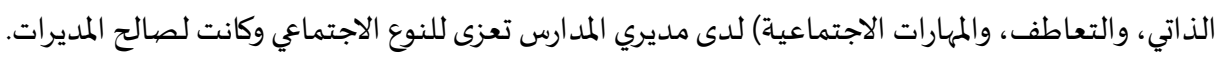

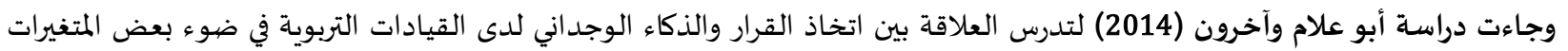

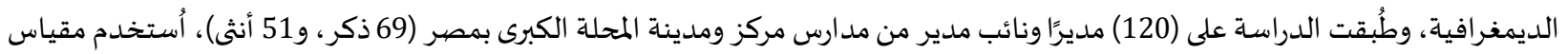

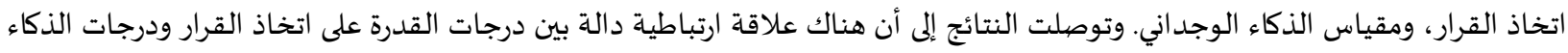

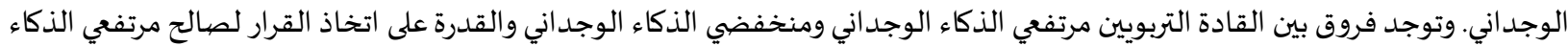

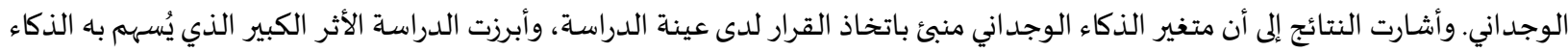

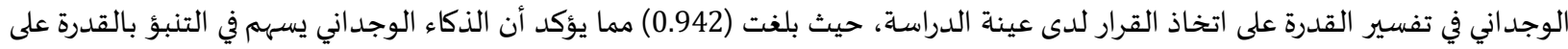
اتخاذ القرارات لدى القيادات التربوية. وأجرى سعادة (2016) دراسة بهدف كشف طبيعة العلاقة بين الذكاء الوجداني والقدرة على القيادة التربوية لدى مديري المؤسسات التعليمية،

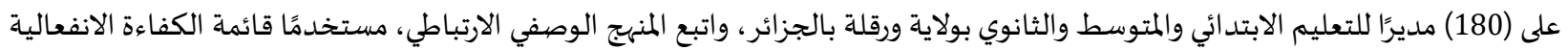

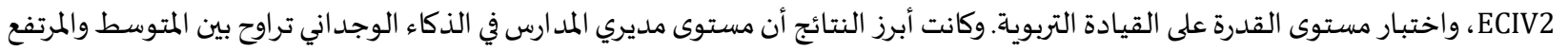

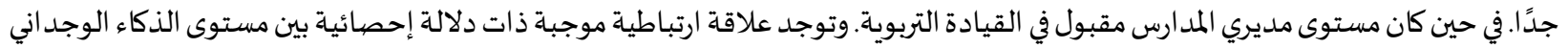

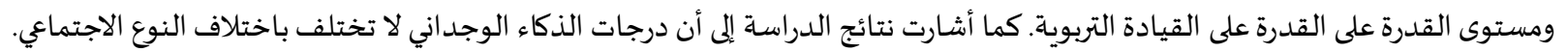
•وهدفت دراسة خلف الله (2016) للتعرف على درجة ممارسة مديري المدارس الأساسية بمحافظة خان يونس بفلسطين لمهارات الذكاء الوجداني

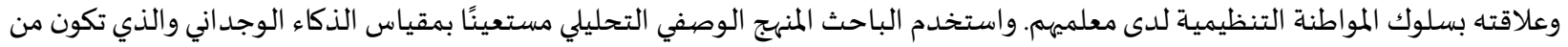

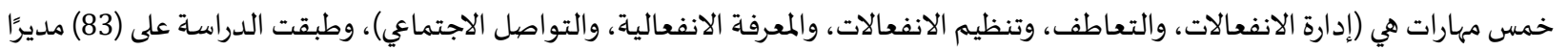

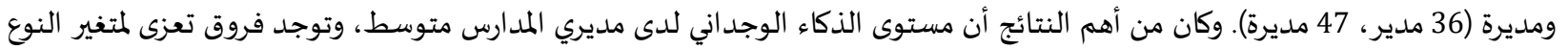
الاجتماعي ولصالح الذكور. أما دراسة صبيرة، وتفاحة (2016) هدفت إلى التعرف على مستوى الذكاء الوجداني لدى مديري المدارس الثانوية في محافظة اللاذقية، ودراسة

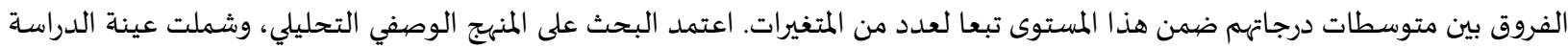

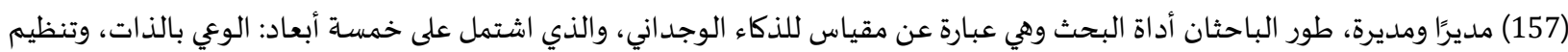

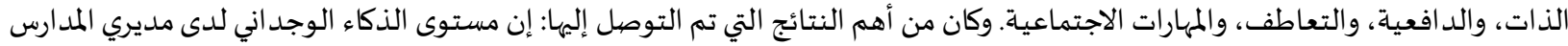
الثانوية مرتفع. ولا توجد فروق في مستوى الذكاء الوجداني تعزى لمتغيري النوع الاجتماعي ومكان الإقامة.

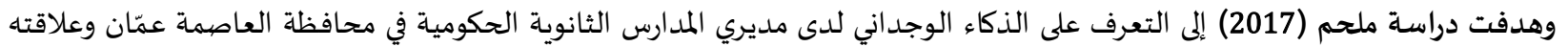

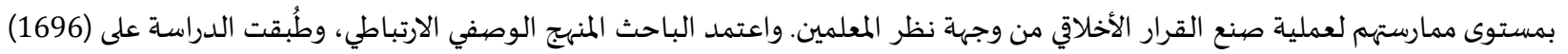

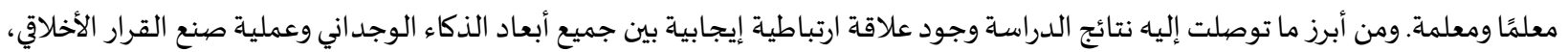

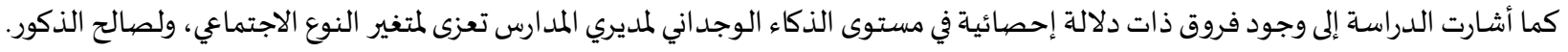
واستقصى ر افيدالي (2017) تأثير مفهوم الذات والنضج الوجداني على سلوك القيادة لدى مديري المدارس الثانوية في ولاية كيرالا.

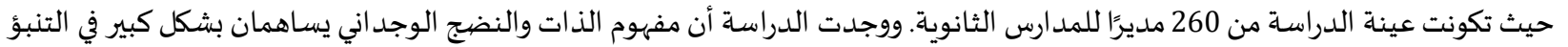




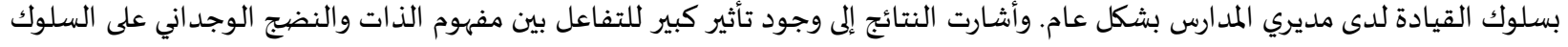

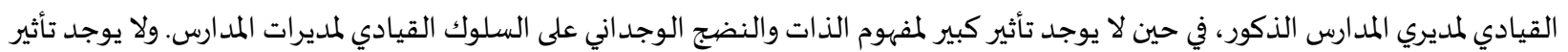

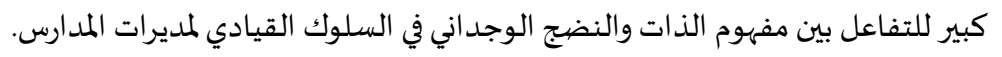

وهدفت دراسة (Maulod, et al., 2017) إلى معرفة العلاقة بين الذكاء الوجداني للمديرين التربويين والممارسات القيادية في المدارس الثانوية

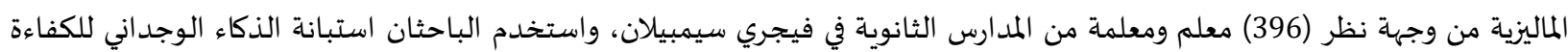

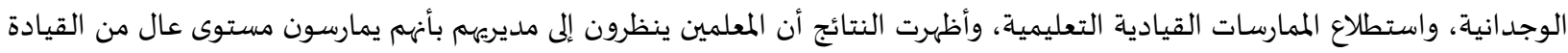

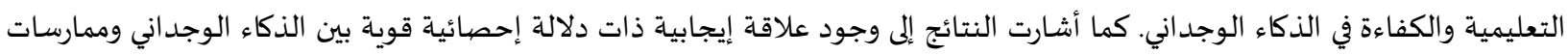

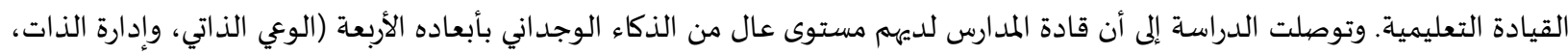

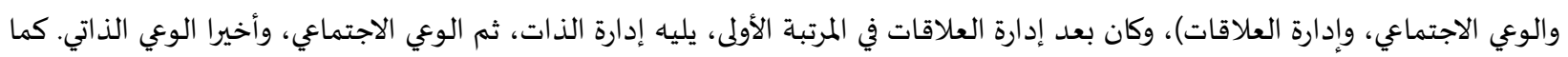

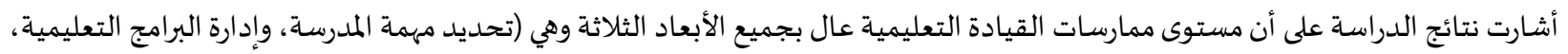

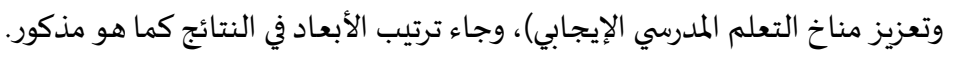

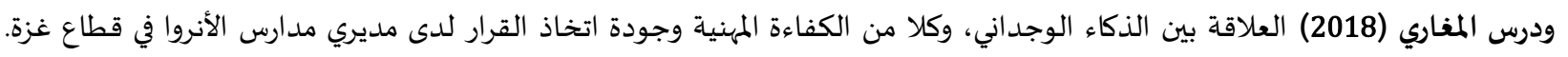

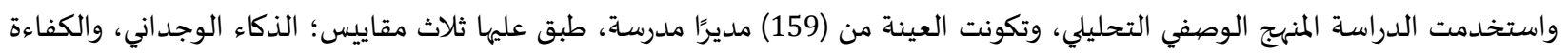

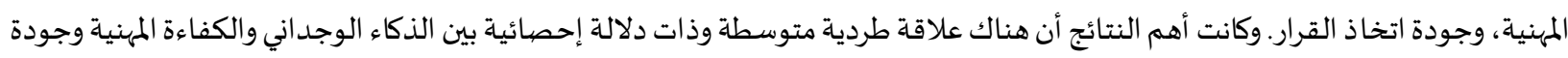
اتخاذ القرار. ولا توجد فروق ذات دلالة إحصائية تعزى لمتغيرات المنطقة التعليمية، والنوع الاجتماتياعي.

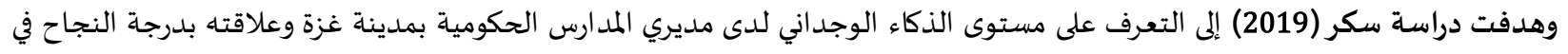

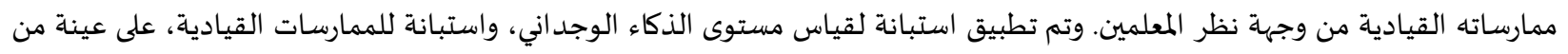

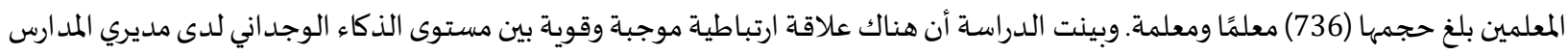

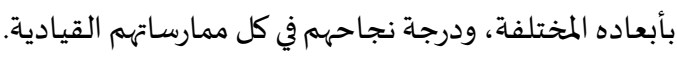
تعقيب على الدراسات السابقة:

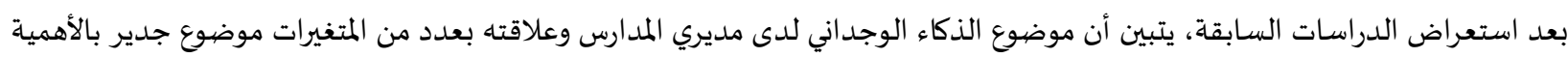

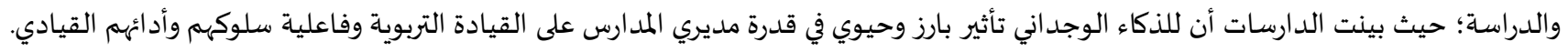

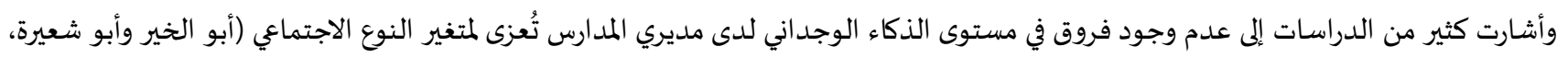

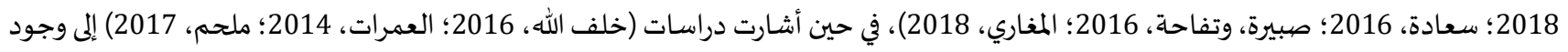

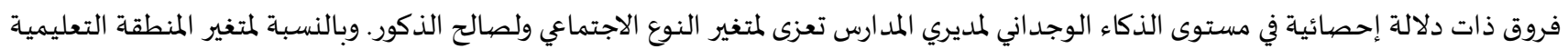

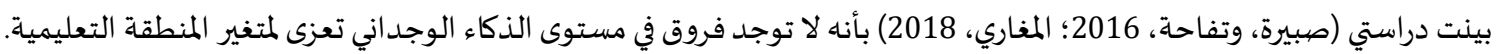

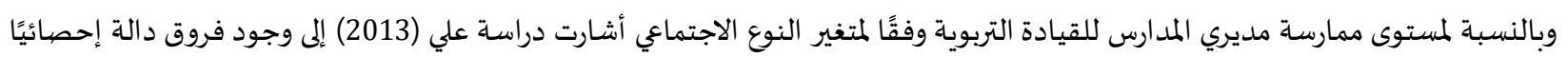

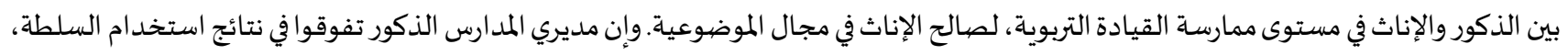

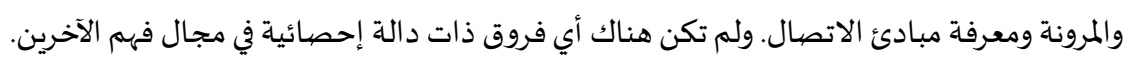

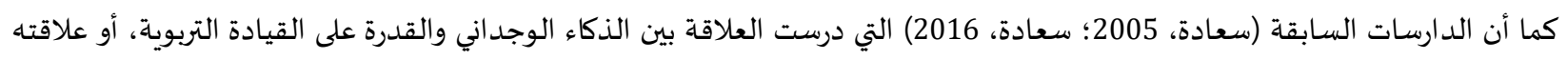

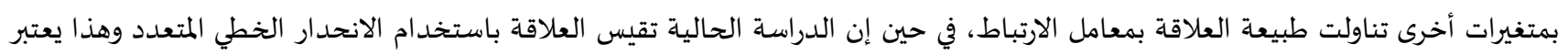

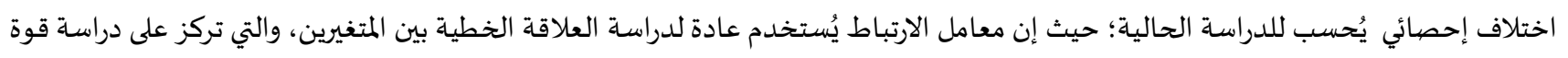

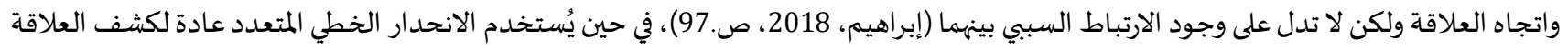

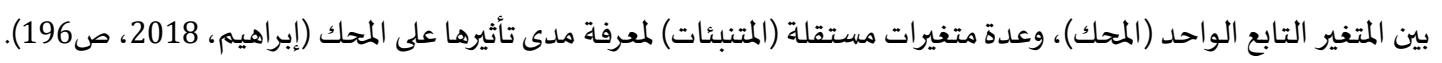

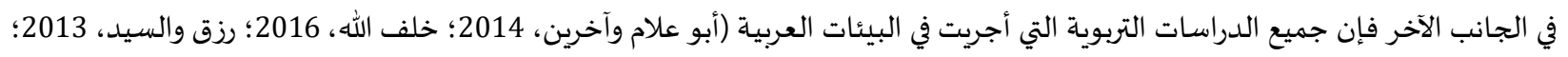

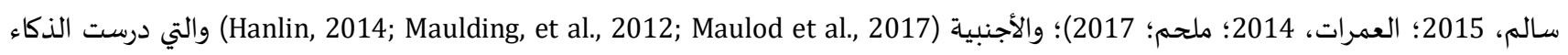

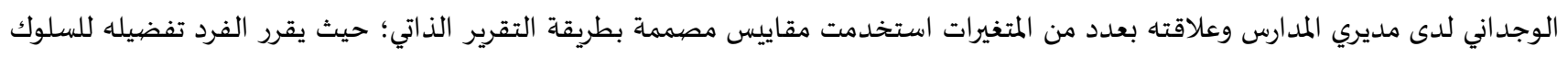

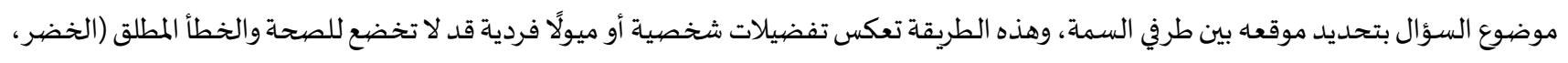

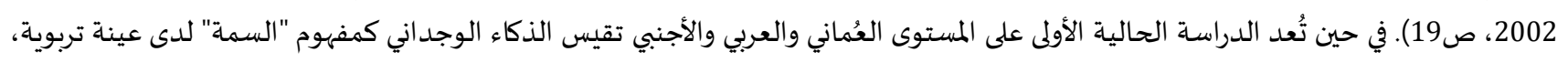

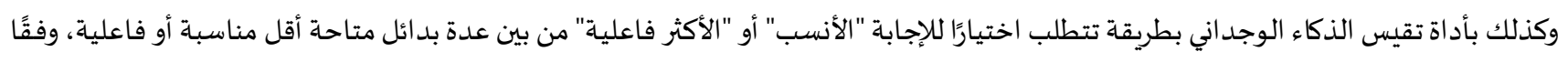

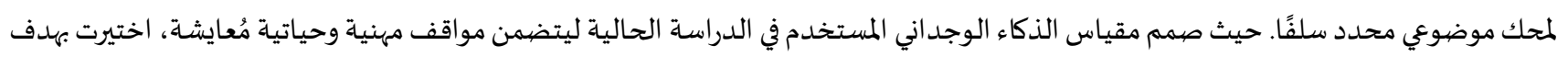


تفادي الاستجابات المتحيزة أو المرغوبية الاجتماعية Social Desirability وهو ما يعاب على وسائل التقرير الذاتي بشكل عام حيث إنها تتأثر بالمرغوبية

الاجتماعية (Singh, 2006, p.175).

3. منهجية الدراسة وإجراءاهها:

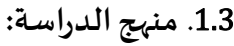

استخدمت الدراسة المنهج الوصفي الارتباطي؛ من خلال دراسة تأثير المتغيرات المستقلة المتمثلة في أبعاد الذكاء الوجداني، في المتغير التابع وهو

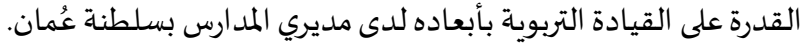

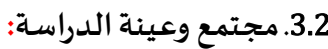

تكون مجتمع الدراسة من مديري ومديرات المدارس العمانيين في سلطنة عُمان، والبالغ عددهم (699) حسب إحصائيات وزارة التربية والتعليم

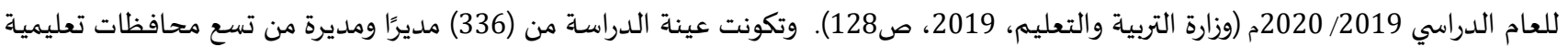
بالسلطنة، وتم اختيار العينة باتباع الطريقة العشوائية البسيطة. ويوضح الجدول (1) توزيع أفراد العينة وفقًا لمتغيرات الدراسة.

\begin{tabular}{|c|c|c|c|}
\hline النسبة المئوية & العدد & الفئات & المتغيرات \\
\hline 57,1 & 192 & أنثى & النوع الاجتماعي \\
\hline 42,9 & 144 & ذكر & \\
\hline 25.6 & 86 & مسقط & المحافظة التعليمية \\
\hline 1.5 & 5 & 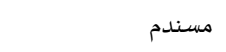 & \\
\hline 2.4 & 8 & البريمي & \\
\hline 15.2 & 51 & الداخلية & \\
\hline 25.6 & 86 & شمال الباطنة & \\
\hline 16.1 & 54 & جنوب الباطنة & \\
\hline 3.9 & 13 & جنوب الشرقية & \\
\hline 4.5 & 15 & الظاهرة & \\
\hline 5.4 & 18 & شمال الشرقية & \\
\hline$\% 100$ & 336 & - & المجموع \\
\hline
\end{tabular}

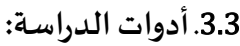

استخدم الباحث في هذه الدراسة مقياسين وهما:

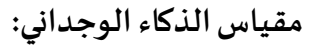

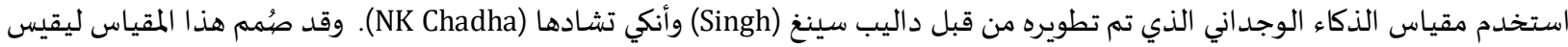

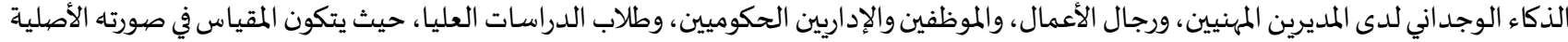

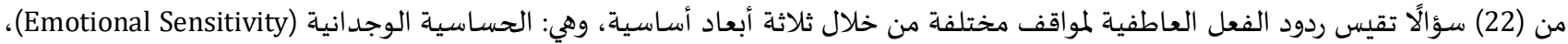

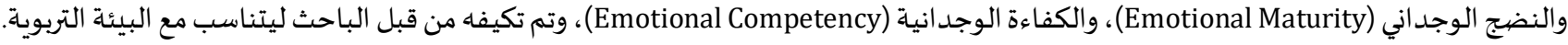

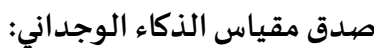

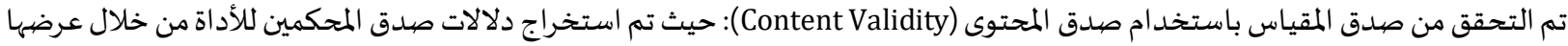

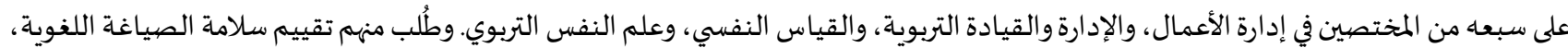

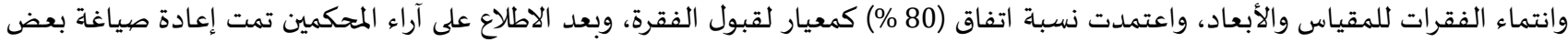
الفقرات، في ضوء ملاحظاتهمه كما تم قياس صدق الاتساق الداخلي (Internal consistency validity)؛ حيث تم حساب معامل الارتباط "بيرسون" بين درجة كل فقرة من فقرات البُعد والدرجة الكلية للبُعد الذي تنتمي إليه هذه الفقرة وتراوحت معاملات ارتباط بيرسون لبُعد الحساسية الوجدانية بين (0,23 إلى 0,78) ، ومعاملات الارتباط لبُعد النضج الوجداني بين (0,24 إلى 0,60)، ومعاملات الارتباط لبُعد الكفاءة الوجدانية بين (0,30 إلى

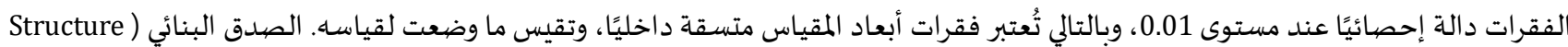

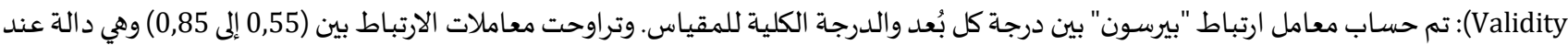

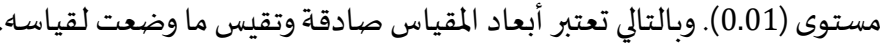




\section{ثبات مقياس الذكاء الوجداني:}

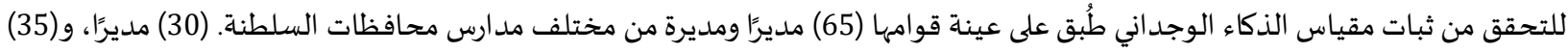

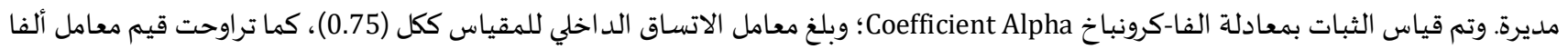

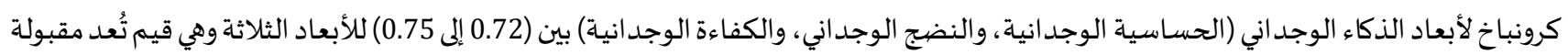

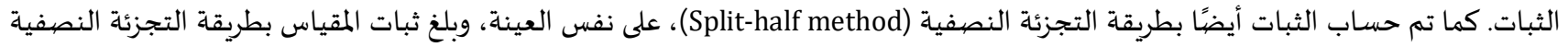

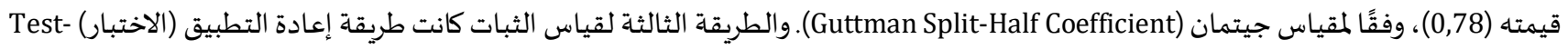
Retest وبلغ معامل الثبات بهذه الطريقة (0,70) وتشير هذه النتائج إلى إمكانية الاعتماد على نتائج المقياس لأهها مؤشرات مقبولة للثبات. • مقياس القدرة على القيادة التربوية: يتكون المقياس من (50) موقفًا موزعين على خمسة أبعاد القداد، كل بُعد منها يقيس جانبًا من الجوانب الرئيسة للقدرة على القيادة التربوية (الموضوعية؛ واستخدام السلطة؛ والمرونة، وفهم الآخرين؛ ومعرفة مبادئ الاتصال). صدق مقياس القدرة على القيادة التربوية: تم التحقق من صدق المقياس بطريقة صدق المحتوى (Content Validity)؛ من خلال آراء المحكمين بمدى أهمية كل موقف من مواقف المقاف المقياس،

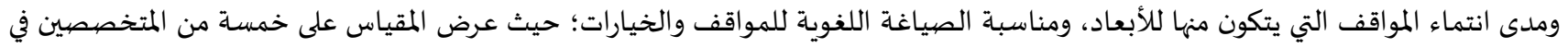

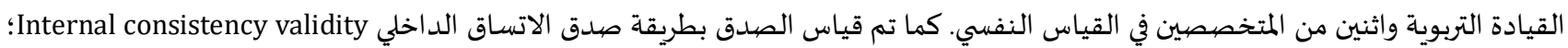

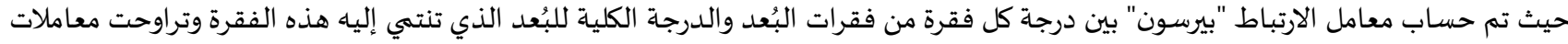

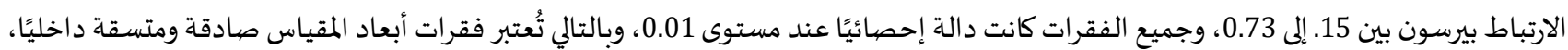

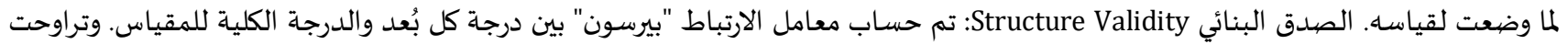

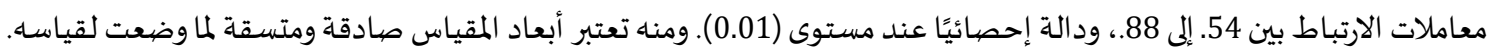
ثبات مقياس القدرة على القيادة التربوية:

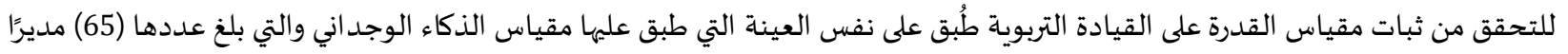

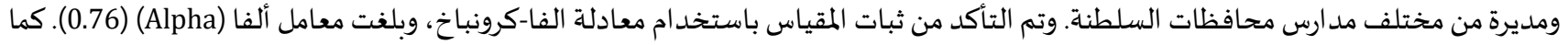

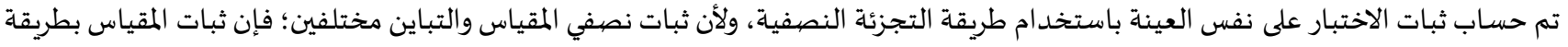

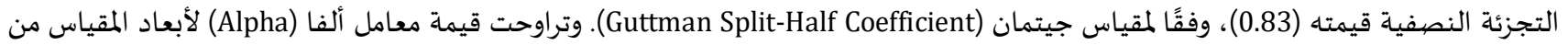

4.3 - 2.3 - المعالجة الإحصائية:

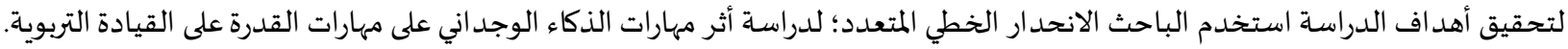

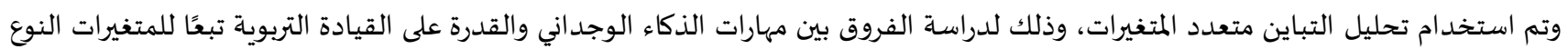
الاجتماعي، والمحافظة التعليمية. مستخدماً برنامج (SPSS).

4. - برض النتائج ومناقشتها 1.4. نتائج السؤال الأول، ونصهه: "ما تأثير أبعاد الذكاء الوجداني (الحساسية الوجدانية، والنضجج الوجداني، والكفاءة الوجدانية) في مهارات القدرة

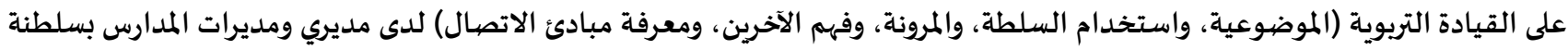
للإجابة على هذا السؤال قام الباحث باستخدام تحليل الانحدار الخطي المتعدد (Multiple linear regression) لتحديد أثر أبعاد الذكاء الوجداني

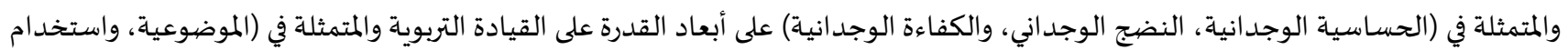
السلطة، والمرونة، فهم الآخرين، ومعرفة مبادئ الاتصال) لدى مديري المدارس بسلطنة عُمان، كما هو مبين في الجدول (2). 
جدول (2): نتائج تحليل الانحدار الخطي المتعدد لقياس أثر أبعاد الذكاء الوجداني على مهارات القدرة على القيادة التربوية

\begin{tabular}{|c|c|c|c|c|c|c|c|c|}
\hline الدلالة & قيمة "ت" & 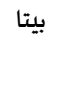 & الدلالة & قيمة "ف" & 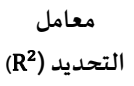 & $\begin{array}{c}\text { الارتباط Rعامل } \\
\text { R }\end{array}$ & المتغيرات المستقلة & المتغير التابع \\
\hline .000 & 4.560 & .241 & .000 & 32.373 & .226 & .476 & الحساسية الوجدانية & الموضوعية \\
\hline .024 & 2.269 & .128 & & & & & النضج الوجداني & \\
\hline .000 & 4.201 & .241 & & & & & الكفاءة الوجدانية & \\
\hline .000 & 5.301 & .298 & .000 & 15.431 & .122 & .350 & الحساسية الوجدانية & استخدام \\
\hline .007 & 2.697 & .163 & & & & & النضج الوجداني & السلطة \\
\hline .172 & 1.370 & .084 & & & & & الكفاءة الوجدانية & \\
\hline .000 & 5.850 & .313 & .000 & 28.792 & .206 & .454 & الحساسية الوجدانية & المرونة \\
\hline .054 & 1.932 & .111 & & & & & النضج الوجداني & \\
\hline .010 & 2.587 & .150 & & & & & الكفاءة الوجدانية & \\
\hline .000 & 7.401 & .369 & .000 & 49.760 & .310 & .557 & الحساسية الوجدانية & فهم الآخرين \\
\hline .014 & 2.474 & .132 & & & & & النضج الوجداني & \\
\hline .000 & 3.785 & .205 & & & & & الكفاءة الوجدانية & \\
\hline .002 & 3.082 & .174 & .000 & 14.595 & .117 & .341 & الحساسية الوجدانية & معرفة مبادئ \\
\hline .009 & 2.622 & .159 & & & & & النضج الوجداني & الاتصبال \\
\hline .077 & 1.775 & .109 & & & & & الكفاءة الوجدانية & \\
\hline
\end{tabular}

أظهرت نتائج الانحدار الخطي المتعدد، كما في الجدول (2) أن هناك أثرًا للذكاء الوجداني على القدرة على القيادة التربوية لدى مديري المدارس

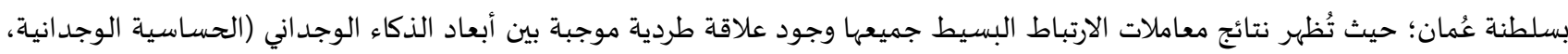
والكفاءة الوجدانية، والنضج الوجداني)، وأبعاد القدرة على القيادة التربوية (الموضوعية، استخدام السلطة، والمرونة، وفهم الآخرين، ومعرفة مبادئ

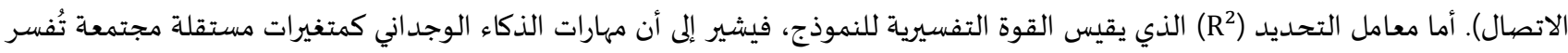
(226.) من التباين في المتغير التابع (الموضوعية) لدى مديري المدارس في سلطنة عُمان. في حين أن مهارات الذكاء الوجداني مجتمعاة تُفسر (122.

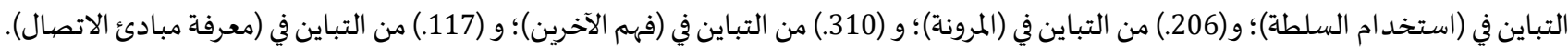

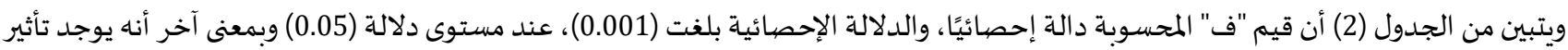

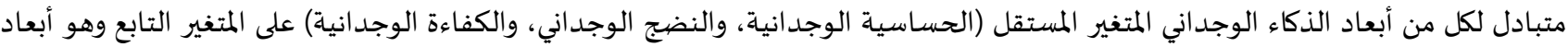

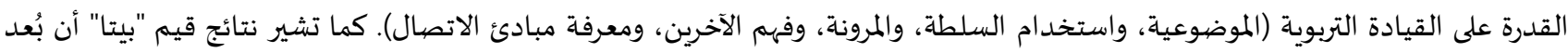
الحساسية الوجدانية له الدور الجوهري الأكبر من بين أبعاد الذكاء الوجداني؛ من حيث التأثير على جميع مهارات القدرة على القيادة التربوية (استخدام

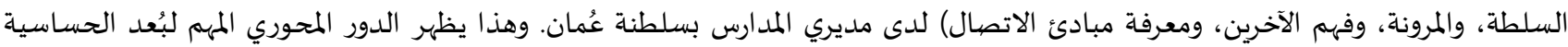

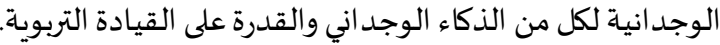

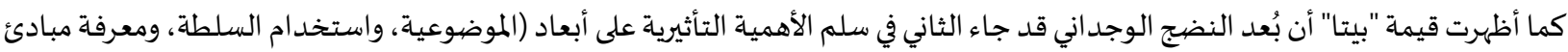
الاتصال) في القدرة على القيادة التربوية. كما أظهرت النتائج أن بُعد النضيج الوجداني كان أقل أبعاد الذكاء الوجداني تأثيرًا في فهم الآخرين لمتغير القدرة

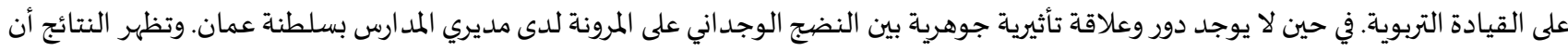
بُعدي الكفاءة الوجد انية والحساسية الوجدانية لهما أكبر الأثر وبعلاقة موجبة على بُعد الموضيوعية في القدرة على بونى القيادة التربوية من بين سائر الأبعاد

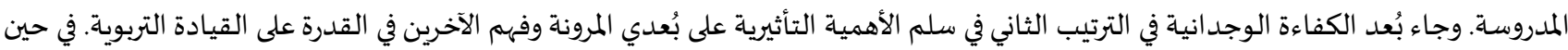
لا يوجد دور وأثر متبادل بين كل من الكفاءة الوجدانية، واستخدام السلطة ، ومعرفة مبادئ الاتصال في القدرة على القيادة التربوية. مناقشـة نتائج السؤال الأول: خلصت نتائج السؤال الأول إلى أن لأبعاد الذكاء الوجداني قدرة في التنبؤ بمستوى موضوعية مديري المدارس في القيادة التربوية وقدرتهم على فهم الآخرين. وأظهرت النتائج أن بُعدي الحساسية الوجدانية والكفاءة الوجدانية لهما أكبر الأثر وبعلاقة موجبة على بُعد الموضوعية في القدرة على القيادة

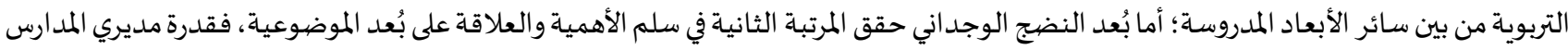
على إدارة انفعالاتهم ومعالجة الجوانب الوجدانية والعاطفية، وقدرتهم على التحكم في مشاعرهم السلبية وتحويلها إلى انفعالات إيجابية، والقدرة على إنى التعامل مع المشاعر بحيث تكون متوافقة مع المواقف المعايشة تجعلهم أكثر شعورا بكفاءتهم الذاتية في التحكم بمختلف الجوانب الإدارية التي تواجههم في بيئة العمل وبالتالي يكونوا أكثر موضوعية (دوغان والظفري، 2016؛ الزومان، 2014). وهذه النتيجة تتفق مع نتائج دراسة (الزعانين، 2018)، من

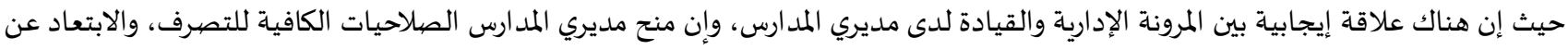

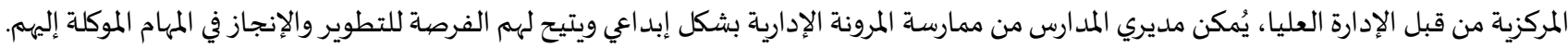

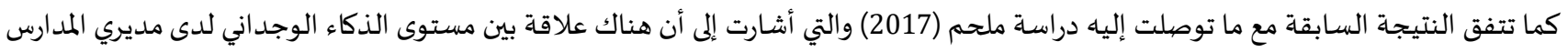


ومستوى ممارستهم لعملية صنح القرار الأخلاقي، حيث إن الذكاء الوجداني لمدير المدرسة يساعده على الوعي بمشاعره، ومن وعي المدير بذاته ينطلق إلى وإلى

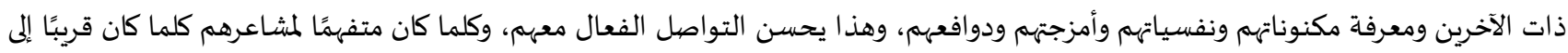

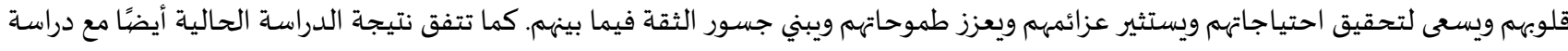

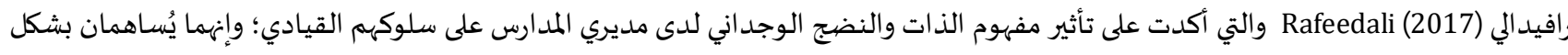
كبير في التنبؤ بسلوك القيادة لديهم.

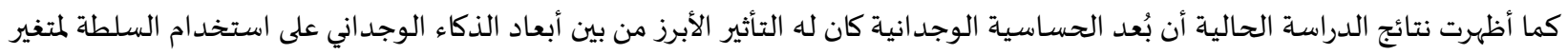

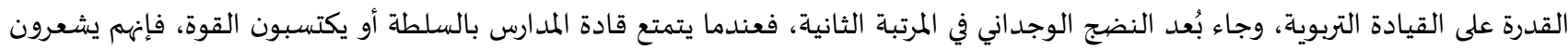

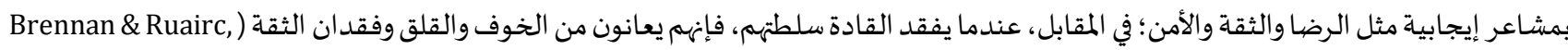

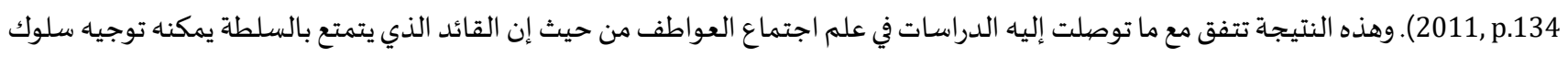

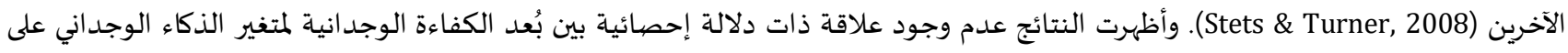

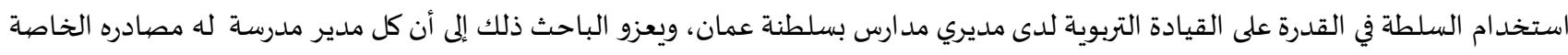

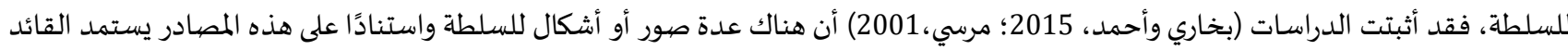

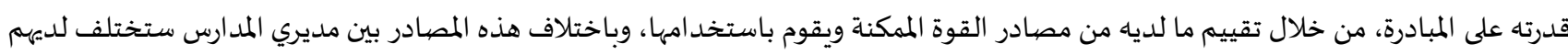

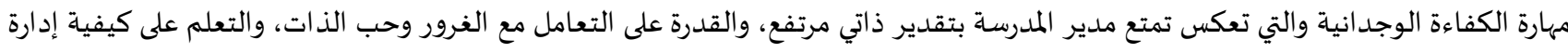

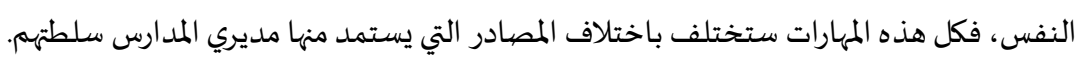

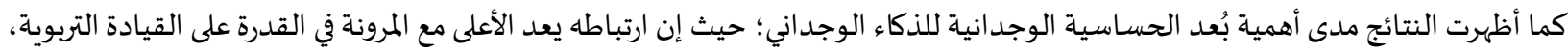

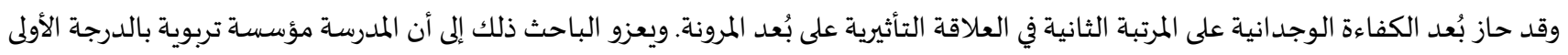

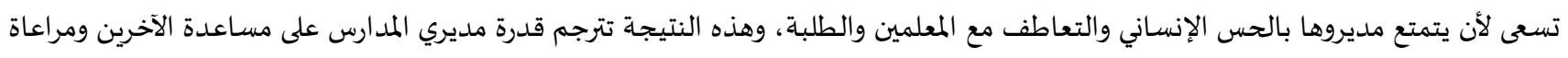

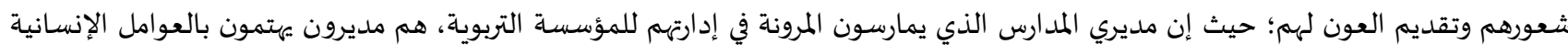

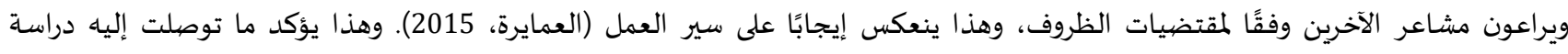
(Pyszczynski at el., 1987)

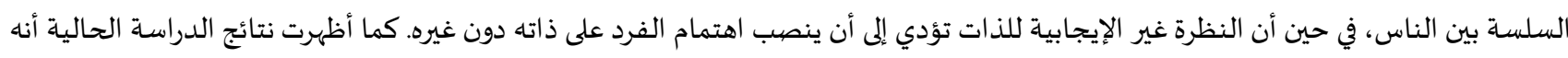

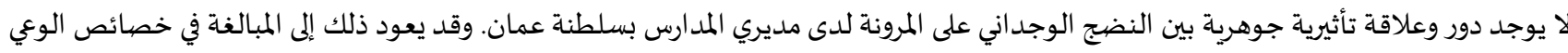

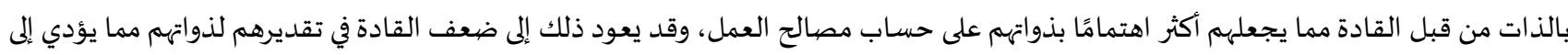

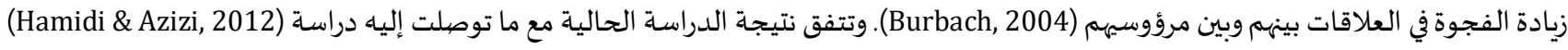

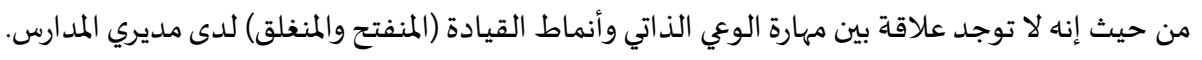

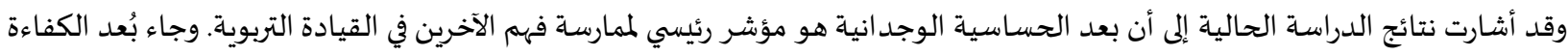

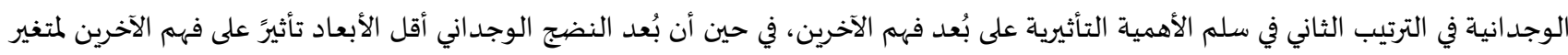

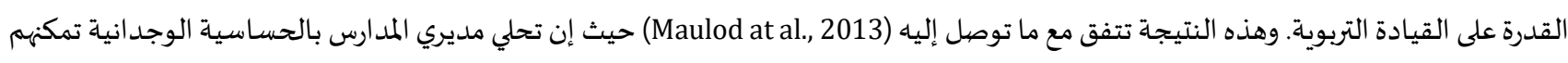

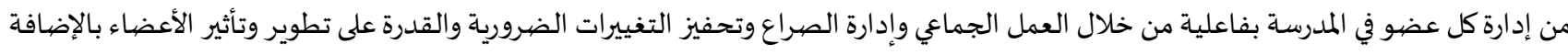

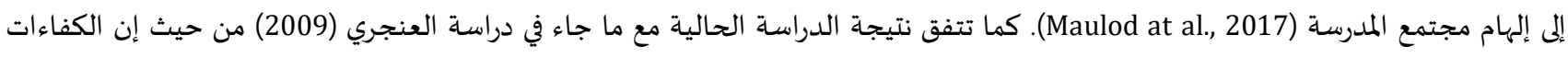

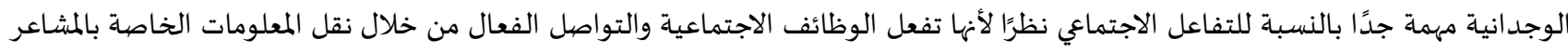

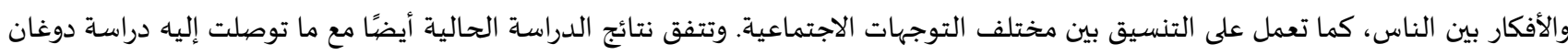

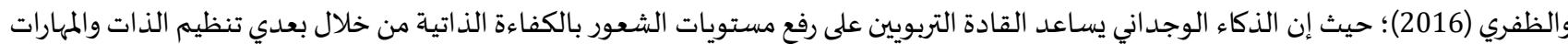

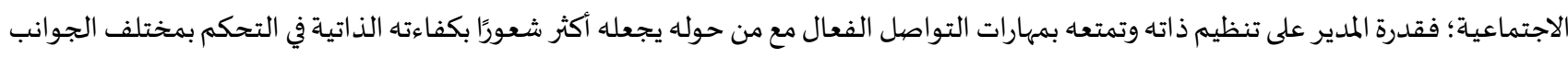

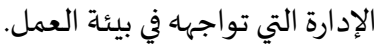

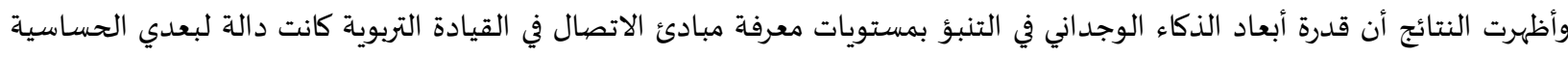

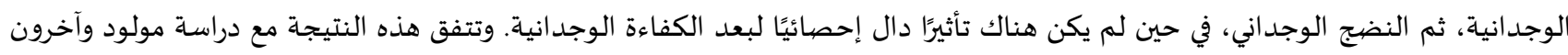
(Maulod et al., 2017)

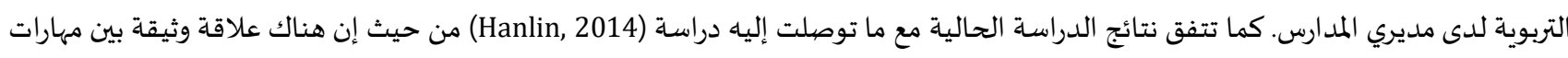

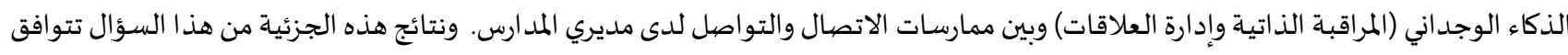

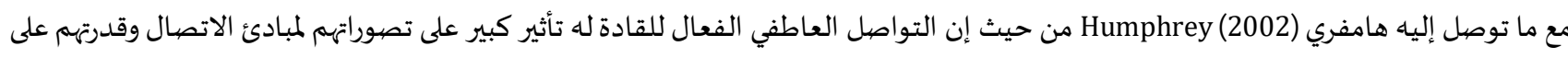


نقل الأفكار ومحتوى الرسائل إلى الآخرين. وتتفق نتيجة الدراسة الحالية مع ما توصلت إليه دراسة الراعي (2013) التي أشارت إلى أن أبعاد إدارة الآخرين

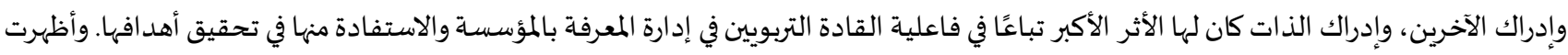
نتائج الدراسة الحالية لا يوجد دور وأثر متبادل بين كل من الكفاءة الوجدانية، ومعرفة مبادئ الاتصال في القدرة على القيادة التربوية. وقد يعزى ذلك إلى إلى

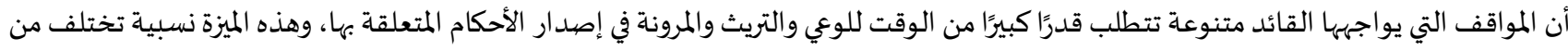

كما أن نتائج هذا الدراسة تؤكد ما توصلت إليه دراسة كردي (2010) والتي أكدت وجود علاقة إيجابية بين الذكاء الوجداني والقدرة على القيادة

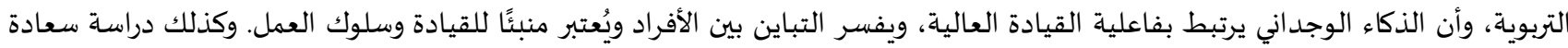

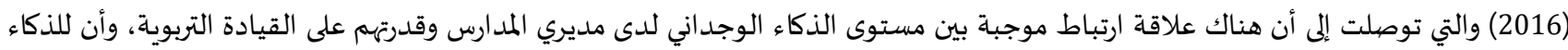

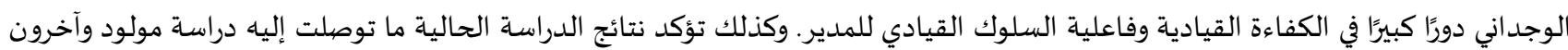
(Maulod et al., 2017) من الذكاء الوجد اني سيُظهر ممارسات قيادية تعليمية عالية.

2.4. نتائج السؤال الثاني، ونصيه: "هل توجد فروق ذات دلالة إحصائية عند مستوى الدلالة ( a c 0.05$)$ بين الذكاء الوجداني والقدرة على القيادة

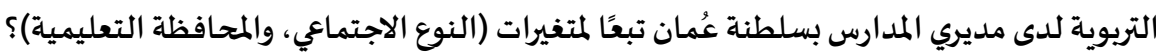
ولإجابة عن هذا السؤال تم استخدام اختبار تحليل التباين متعدد المتغيرات (MANOVA)، لمتنيرات النوع الاجتماعي (ذكور/ إناث)، والمحافظة التعليمية، والجدول (3) يوضح نتائج هذا التحليل.

جدول (3): تحليل التباين متعدد المتغيرات تبعًا للنوع الاجتماعي والمحافظة التعليمية

\begin{tabular}{|c|c|c|c|c|c|c|c|}
\hline التفسير & مستوى الدلالة & "فيمة & متوسط المربعات & درجة الحرية & المتغير الديموغرافي & الأبعاد & المتغير \\
\hline دال إحصائيًا & .011 & 6.517 & 24.385 & 1 & النوع & الحساسية الوجدانية & \multirow{3}{*}{ الوجداني } \\
\hline غير دال & .843 & .039 & .110 & 1 & النوع & النضج الوجداني & \\
\hline غير دال & .496 & .465 & 1.856 & 1 & 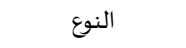 & الكفاءة الوجدانية & \\
\hline دال إحصائيًا & .020 & 5.435 & .257 & 1 & النوع & الموضوعية & \multirow{5}{*}{ التربوية } \\
\hline غير دال & .253 & 1.310 & .029 & 1 & 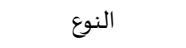 & استخدام السلطة & \\
\hline غير دال & .132 & 2.283 & .066 & 1 & 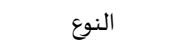 & 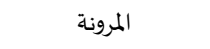 & \\
\hline غير دال & .052 & 3.789 & .236 & 1 & 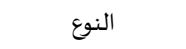 & فهم الآخرين & \\
\hline دال إحصائيًا & .001 & 11.310 & .262 & 1 & 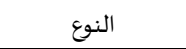 & معرفة مبادئ الاتصال & \\
\hline غير دال & .084 & 1.761 & 6.589 & 8 & المحافظة & الحساسية الوجدانية & \multirow{3}{*}{ الوجداني } \\
\hline غير دال & .835 & .529 & 1.477 & 8 & المحافظة & النضج الوجداني & \\
\hline غير دال & .388 & 1.064 & 4.246 & 8 & المحافظة & الكفاءة الوجدانية & \\
\hline غير دال & .114 & 1.634 & .077 & 8 & المحافظة & الموضيوعية & \multirow{5}{*}{ التربوية } \\
\hline دال إحصيائيًا & $.032 *$ & 2.144 & .048 & 8 & المحافظة & استخدام السلطة & \\
\hline غير دال & .065 & 1.865 & .054 & 8 & المحافظة & 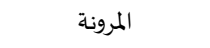 & \\
\hline غير دال & $.049^{* *}$ & 1.979 & .123 & 8 & المحافظة & فهم الآخرين & \\
\hline غير دال & .537 & .876 & .020 & 8 & المحافظة & معرفة مبادئ الاتصال & \\
\hline
\end{tabular}

تم عرض النتائج الموضحة في الجدول (3) تبعًا لكل متغير على النحو التالي: • • النتائج المتعلقة بالفروق بين الذكاء الوجداني والقدرة على القيادة التربوية لدى مديري المدارس تبعًا لمتنغير (النوع الاجتماعي):

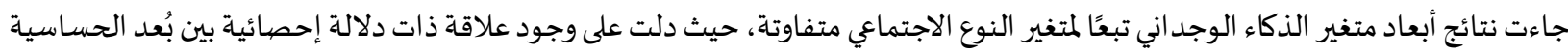
الوجدانية تبعًا للنوع الاجتماعي، فقد بلغت قيمة "ف" المحسوبة (6.517)، وقيمة الدلالة الإحصائية (0.011) وبالتالي فهي أقل من مستوى دلالة

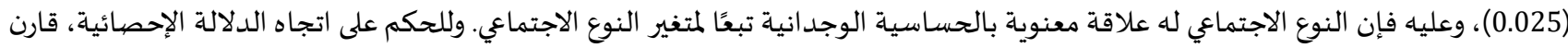

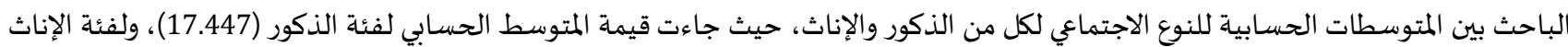
(18.309). وعليه فإن قيمة الدلالة الإحصائية تتجاء لصالح الإناث. كما أظهرت النتائج عدم وجود فروق ذات دلالة إحصائية عند مستوى دلالة (0.05) بين بُحدي النضج الوجداني ("ف" المحسوبة= 0.039، مستوى الدلالة= 0.843) والكفاءة الوجدانية ("ف" المحسوبة= 0.465، مستوى الدلالة= لمتغير الذكاء الوجداني تبعًا لمتغير النوع الاجتماعي. 
أما بالنسبة لدراسة الفروق بين أبعاد متغير القدرة على القيادة التربوية تبعًا لمتغير النوع الاجتماعي، فقد أظهرت النتائج وجود فروق ذات دلالة

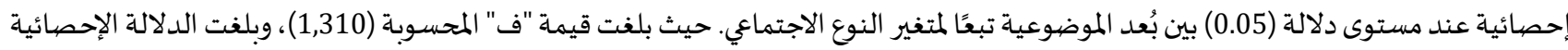
قيمة (0.020). وبلغت قيمة المتوسط الحسابي لفئة الذكور (0.663). ولفئة الإناث (0.752). مما يدل على أن اتجاه الدلالة الإحصائية لصالح الحئ الإناث. وأظهرت النتائج أيضًا وجود فروق ذات دلالة إحصائية عند مستوى دلالة (0.05) بين بُعد معرفة مبادئ الاتصال في القدرة على القيادة التربوية تبعًا لمتغير النوع الاجتماعي ("ف" المحسوبة= 11.310، مستوى الدلالة= 0.001).وتشير قيم المتوسطات الحسابية لكل من الذكور (0.477) والإناث (0.566)، إلى أن اتجاه الدلالة الإحصائية لصالح الإناث. في المقابل أظهرت النتائج عدم وجود دلالة إحصائية بين كل من استخدام السلطة ("ف" المحسوبة.

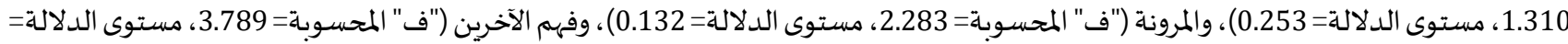
0.052) تبعًا لمتغير النوع الاجتماعي؛ وذلك لأن مستوى دلالتها جاء أكبر من مستوى (0.05) مما يدل على انتفاء الفروق.

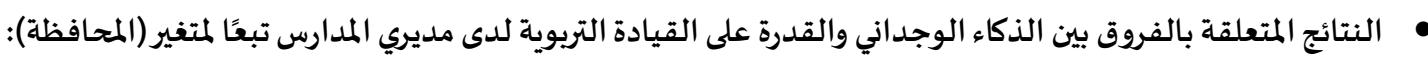

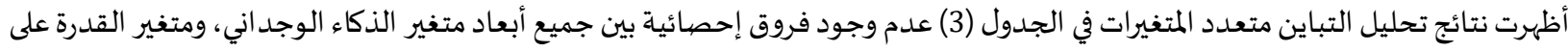

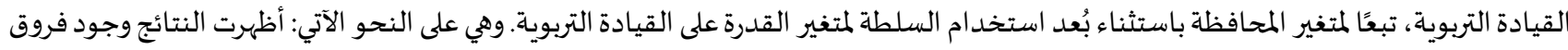

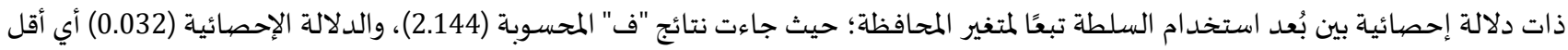

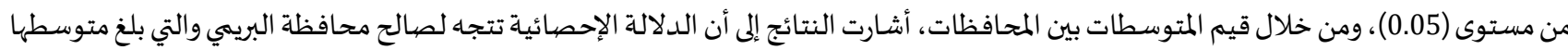
الحسابي (0.613)، بينما جاءت قيمة المتوسطات للمحافظات الأخرى أقل من هذه القيمة وهي على النحو الآتي: (مسقط فئ 0.582، 0.582، وجنوب الباطنة =

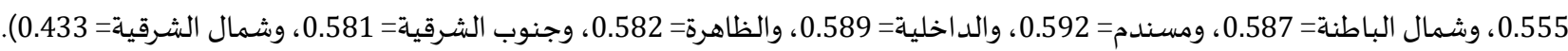

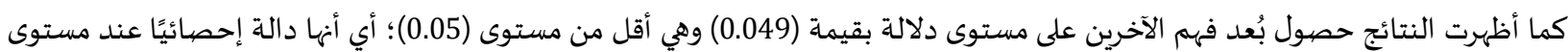

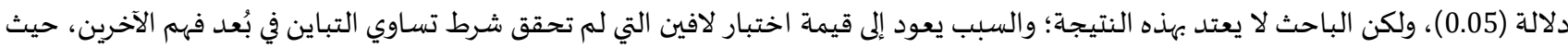

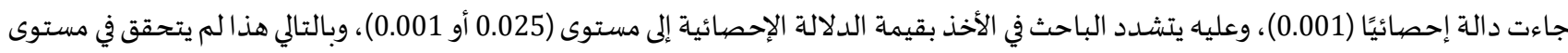

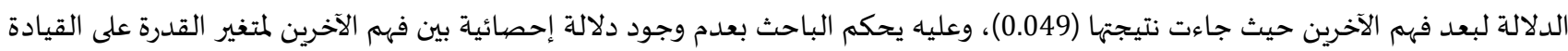
التربوية تبعًا لمتغير المحافظة. كما أظهرت النتائج عدم وجود دلالة إحصائية بين جميع أبعاد متغير الذكاء الوجداني والمتمثلة في الحساسية الوجدانية ("ف" المحسوبة= 1.761، مستوى الدلالة= 0.084)، والنضيج الوجد اني ("ف" المحسوبة= 0.529، مستوى الدولالة=

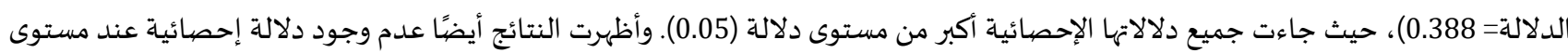

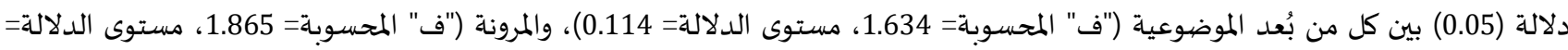

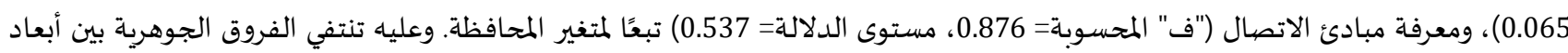
الذكاء الوجداني (الحساسية الوجدانية، والنضج الوجداني، والكفاءة الوجدانية) وأبعادية المادواد القدرة على القيادة التربوية (الموضوعية، والمرونة، وفهم

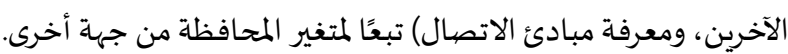
مناقشـة نتائج السؤال الثاني:

• مناقشَة النتائج المتعلقة بالفروق بين الذكاء الوجداني والقدرة على القيادة التربوية لدى مديري المدارس تبعًا لمتغير (النوع الاجتماعي): أظهرت النتائج وجود فروق جوهرية في مستوى ممارسة مديري المدارس بسلطنائة عُمان لمهارات القيادة التربوية المتمثلة في (الموضيوعية، ومعرفة

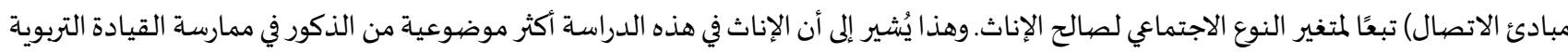

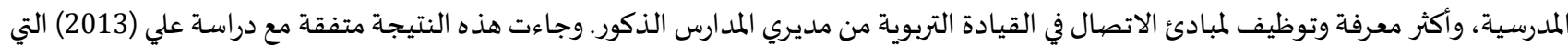

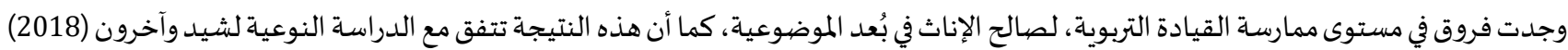

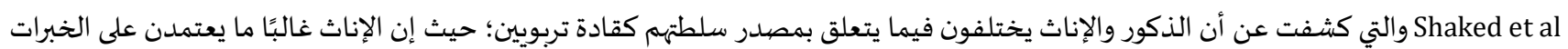
والمعرفة التعليمية، في حين اعتمد الذكور على السلطة الممنوحة لهم بموجب اللوائح، وكذلك مهاراتهم في صنع القرار.

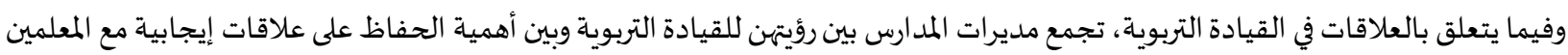

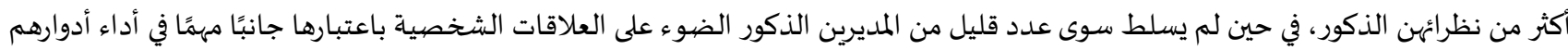

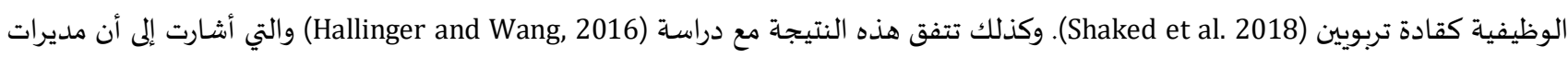

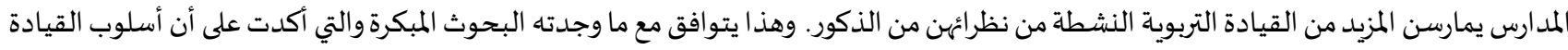

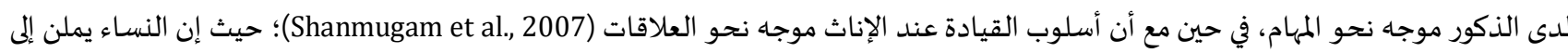

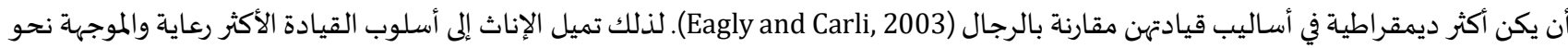

العلاقات، بينما يُظهر الرجال أسلوب قيادة أكثر استبدادية (Eagly and Johnson, 1990). 
في المقابل أظهرت النتائج عدم وجود دلالة إحصائية بين كل من استخدام السلطة وفهم الآخرين والمرونة تبعًا لمتنير النوع الاجتماعي. مما يدل على فئل

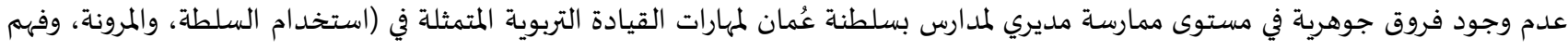

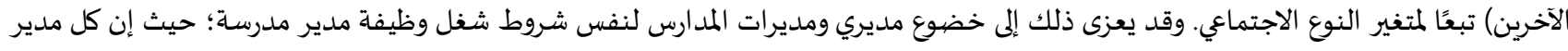

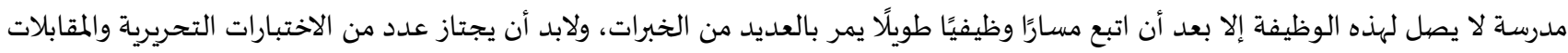

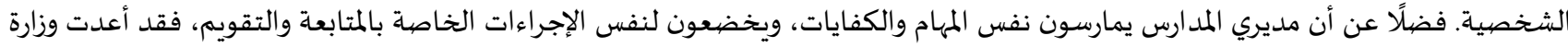

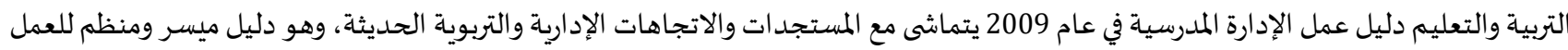

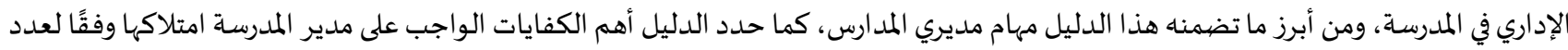

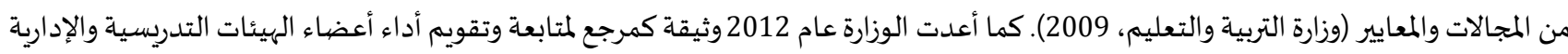
والإشرافية (وزارة التربية والتعليم، 2012).

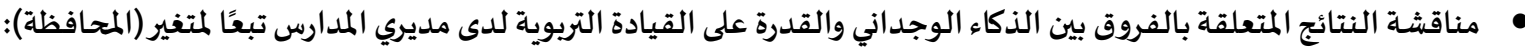

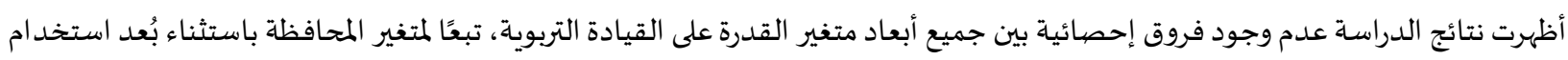

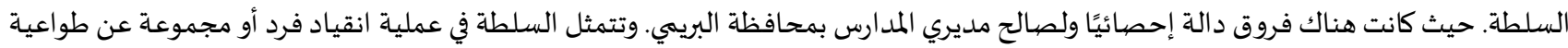

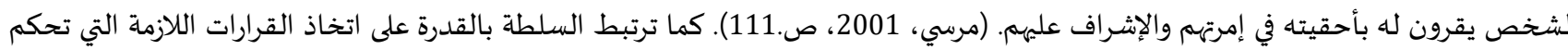

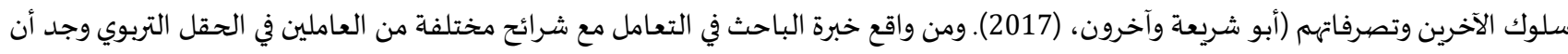

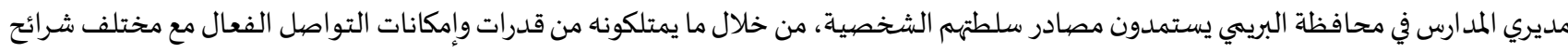

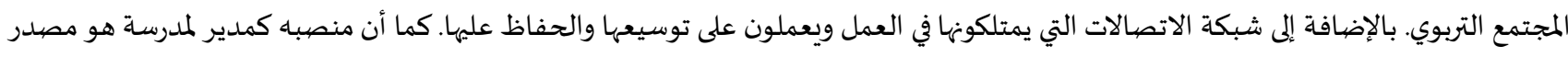
آخر من مصادر قوتهم وتميزهم، وترتبط هذه القوة مباشرة بموقع القائد على الخربطة التنفيذية في المؤسسة التربوية، حيث يشرف مدير المدرسة على 70 مدئ

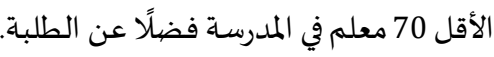
كما أظهرت النتائج عدم وجود فروق ذات دلالة إحصائية بين أبعاد القدرة على القيادة التربوية المتمثلة في (الموضوعية، والمرونة، وفهم الآخرين،

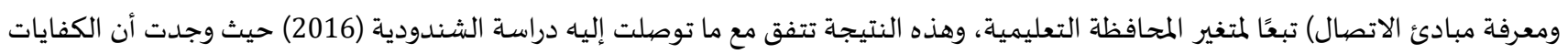

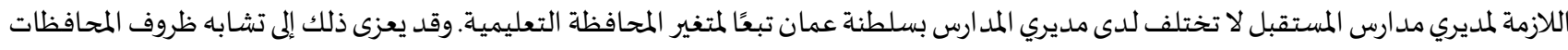

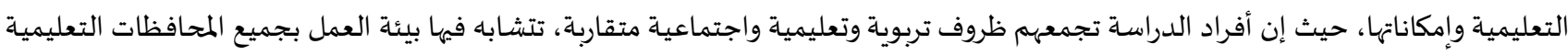

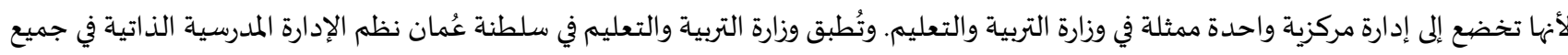

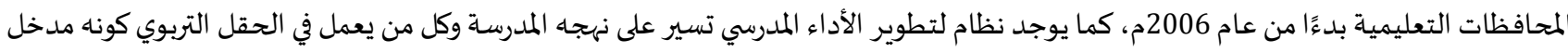

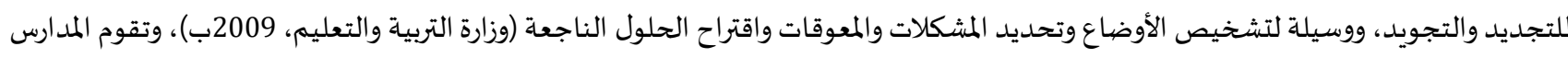
بممارسة عدد من الصلاحيات والمسؤوليات الإدارية والفنية كوحدة تدير نفسها ذاتيًا في حدود السياسة التعليمية العامة لوزارة التربية والتعليم (الهادي،

(2009

3.4 التوصيات:

تحديث وتجديد برامج إعداد الكفايات التربوية في كليات التربية، بما يتوافق مع المستجدات والاتجاهات الإدارية والتربوية الحديثة. أهمية استخدام أدوات التقييم القياسية للذكاء الوجداني في برامج التطوير المهني، باعتبار ذلك جزءًا من عملية تقييم مديري المدارس قبل فيل الشروع في تعيينهم، وكذلك في عملية التخطيط والترقيات. التركيز على بعض المهارات الفنية والإدارية في برامج إعداد مديري المدارس مثل: اتخاذ القرارات، والتواصل الإنساني والتربوي الفعال، وإدارة التغيير. تنظيم عدد من البرامج التدريبية الفعالة لمديري المدارس لتعزيز الكفاءات الوجدانية والاجتماعية وقدرتهم على القيادة التربوية. دعم وتشجيع إدارات المدارس التي تقودها المرأة (المديرة) من خلال الاهتمام وإبراز أعمالها ومواكبة تطويرها نحو الأفضل. تشجيع وتحفيز مديري المدارس على الالتحاق ببرامج وندوات علمية إثرائية بغض النظر عن سنوات الخدمة أو الخبرة من أجل تجديد وتطوير خبراتهم في مجال القيادة التربوية.

4.4 المقترحات البحثية: إجراء دراسة للتعرف على أثر الخبرة والمؤهل الأكاديمي والمرحلة التعليمية على مستوى توظيف مديري المدارس بسلطنة عُمان لمهارات الذكاء الوجداني، وقدرات القيادة التربوية.

إجراء دراسة أخرى باستخد ام منهج علمي مختلف، مثال على ذلك: إعداد دراسة نوعية للدراسات والبحوث التي درست المتغيرات المتعلقة بالعمل

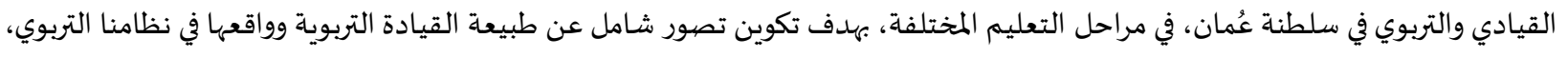


من حيث التحديات والمشكلات، والنجاحات، ليتسنى للمعنيين بالأمر من تحديد الأهد اف ورسم السياسات والاستراتيجيات، الكفيلة بتجاوز تلك التحديات ودعم تلك الإيجابيات.

دراسـة فاعلية برنامج تدريبي في تنمية مهارات الذكاء الوجداني لدى عينة من مديري المدارس بسلطنة عُمان. دراسة فاعلية برنامج تدريبي في تنمية قدرات القيادة التربوية لدى عينة من مديري المدارس بسلطنة عُمان.

أولاً: المراجع العربية:

1. إبراهيم، م. (2018). التحليل الإحصيائي للبيانات من المرحلة الابتدائية إلى المتقلدمة باستخدام الحزهة الإحصائية للعلوم الإنسانية SPSS. ماليزيا: جامعة العلوم الاسلامية الماليزية. 2. أحمد، أ. (2000). الجوانب السلوكية في الإد/رة الممدرسية. القاهرة: دار الفكر العربي.

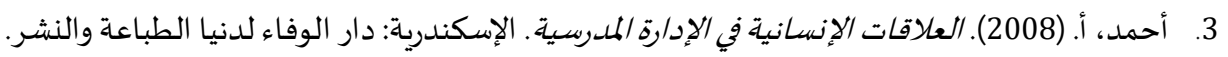
4. أبو الخير، أ، وأبو شعيرة، ن. (2018). مستوى الذكاء الوجداني وعلاقتاء بتحسين أداء مدير المدارس في المرحلة الأسـاسية الدنيا التابعة لوكالة

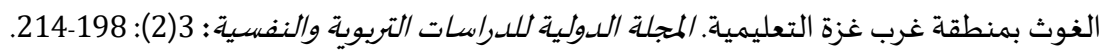
5. أمبوسعيدية، م. (2012). تطوير إدارة مدارس التعليم الأساسي في ضيوء مدخل التخطيط الاستراتيجي بسلطنة عمان. (رسالة ماجستير غير منشورة). جامعة نزوى. 6. وجهة نظر المعلمين. مجلة كلية التوبية: (163): 489-534. 7. بروال ، م. (2015). الكفاءة التواصلية في الإدارة المدرسية في ضوء آلمعهية آراء أساتذة التعليم الثانوي. مجلة العلوم النفسية والتوبوية: 1(1): 109-138.

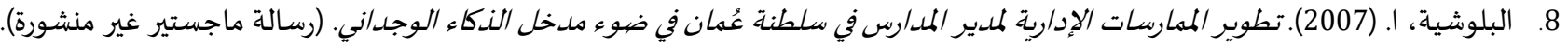
جامعة السلطان قابوس. 9 . البوسعيدي، ح. (2011). الكفايات الإدارية للدى مديري مدارس التعليم الأساسي في ضوء متطلبات مدرسة المستقبل في سلطنة عُمان. (رسالة ماجستير غير منشورة). جامعة مؤته. 10. الجابرية، ي. (2017). مهارات التواصل لدى مديري مد/رس الحلقة الثانية بسلطنة عُمان وعلاقتها ببعض المتغيرات. (رسالة ماجستير غير منشورة). جامعة نزوى. 11. جلال، خ. (2010). أساليب /تخاذ القراروتقدير الذات لدى كل من ملديري المدارس وطلاب الجامعة. المؤتمر الإقليمي الثاني لعلم النفس، القاهرة: رابطة الأخصائيين النفسيين المصرية.

12. حبيشي، ع. (2012). قياس القدرة على القيادة التربوية لمديري ومديرات المدارس الثانوية في محافظة عدن. مجلة كلية التوبية:(12): 143-167). 13. الحراحشـة، م. (2013). درجة الذكاء الوجداني لدى مديري مدارس مديرية التربية والتعليم للواء قصببة محافظة المفرق في الأردن. مجلة المنارة: 19 .383-353:(3)

14. حريزي ، م. (2013). دراسة نقدية لبعض المناهج الوصفية وموضوعاتها في البحوث الاجتماعية والتربوية والنفسية". مجلة العلوم الإنسانية والاجتماعية: (13): 23-14 جريزي م. 15. الحمد اني، ر. (2014). الإبداع الانفعالي وعلاقته بالقيادة التربوية لدى مدراء المدارس الثانوية. مجلة جرش للبحوث والدراسات الأردن: 15 (2): 17.35 16. خلف الله، م. (2016). الذكاء الوجداني لدى مديري المدارس الأسـاسية بمحافظة خان يونس وعلاقته بسلوك المواطنة التنظيمية لدى معلميهم. مجلة الجامعة الإسلامية للدراسيات التوبوية والنفسية: 24(3): 129-151.

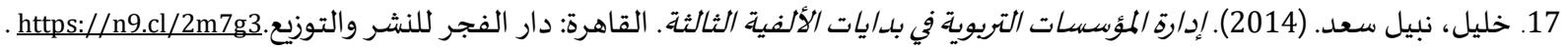
18. دوغان، ن؛ والظفري، س. (2016). معتقدات الكفاءة الذاتية وعلاقتها بالذكاء الوجداني وبعض المتحنغيرات الشخصية والمدرسية لدى الإداريين

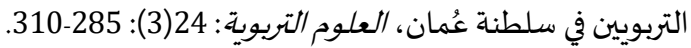

19. رزق، ر؛ والسيد، م. (2013). مكونات الذكاء الوجداني وعلاقتها بمهارات اتخاذ القرار لدى مديري المدارس". المجلة المانة التويوية: (34): 223-272.

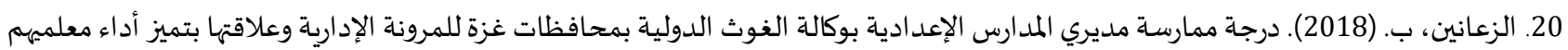

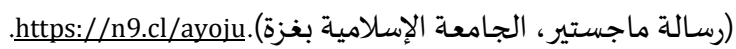


21. الزومان، م. (2014). مستوى الذكاء الوجد/ني لدى القادة، دراسة ميد/نية على الأجهزة الحكومية بالمملكة العبية السعودية. القاهرة: المؤسسة العربية للتنمية الإدارية.

22. سالم، ب. (2015). الذكاء العاطفي لمديري المدارس الثانوية بمحافظات غنزةوعلاقته بالولاء التنظيمي للمعلمين. (رسالة ماجستير، أكاديمية الإدارة

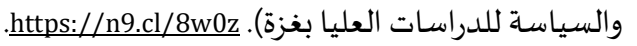
23. سعادة، ر. (2016). الذكاء الوجداني في علاقته بالقدرة على القيادة التربوية لدى مديري المؤسسات التعليمياة. المجلة التونسية للعلوم الاجتماعية: $.92-71:(143) 51$

24. سعادة، ر. (2005). الذكاء الانفعالي وعلاقته بالقيادة التربوية لدى مديري التعليم الإكمالي والثانوي. (رسالة ماجستير). كلية الآداب والعلوم الإنسانية. جامعة ورقلة، الجزائر.

25. السعود، ر. (2013). القيادة التويوية (مفاهيم وآفاق). الأردن: دار صففاء للنشر والتوزيع. 26. سكر ، ن. (2019). مستوى الذكاء الوجداني لدى مديري المدارس الحكومية بمدينة غزة وعلاقتاه بدرجة النجاح في ممارساته القيادية من وجهة نظر

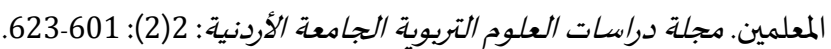
27. الشامان، أ. (2006). مدى فاعلية الذكاء الوجداني في تطوير مهارات القيادة التربوية. مجلة جامعة الأمام محممد بن سعود الإسعامية: (55): 470-

28. شاهين، ع. (2011). درجة ممارسة الملديرين الجدد للمهارات القيادية في المدارس الحكومية بمحافظات غنقة من وجهة نظرهمروسبل تنميتها. (رسالة ماجستير ، الجامعة الإسلامية بغزة). 29. أبوشريعة، محمد، جويفل، ومصطفى، والحسنات، حسن. (2017). أنماط السلوك القيادي وعلاقتاه بتفويض السلطة لدى مديري ومديرات المدارس في مديريتي تربية البادية الجنوبية ومعان في الأردن من وجهة نظر المعلمين والمعلمات. مجللة جامعة الحسين بن طلال للبحسوث: 3(2): 128.https://n9.cl/5pd9h .159 30. الشمري، ر. (2016). درجة ممارسة أبعاد الذكاء الوجداني لدى القيادات التربوية في المدارس الأهلية بالرياض. مجلة كلية التوبية: جامعة الأزهر، .174-143: 168

31. صببيرة، ف؛ وتفاحة، ع. (2016). مدى توافر الذكاء الوجداني لدى مديري المدارس الثانوية في محافظة اللاذقية. مجلة جامعة تشرين للبحوث والدراسات العلمية: 38 (6)، 321-321.

32. الصعيدي، هـ. (2015). مستوى ممارسة القيادة التربوية لدى مديرات المدارس الثانوية للبنات بجدة. مجلة التببية: جامعة الأزهر: 163 (3)، 257-

33. عشيبة، ف؛ أبو حلوة، م. (2009). تدربب مديري المدارس على الذكاء الوجداني وانعكاساته على سلوكهم القيادي بوصفة متطلبًا لمجتمع التعلم.

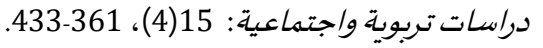

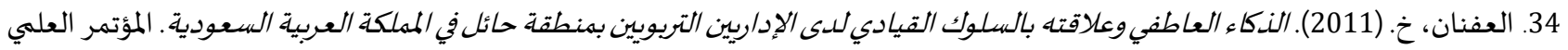
العربي الثامن لرعاية الموهوبين والمتفوقين: المجلس العربي للموهوبين والمتفقين الأردن.

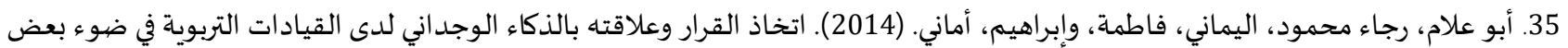

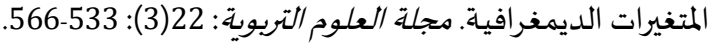
36. علي، ع. (2008). بحث مقارن لدرجة ممارسة القيادة التربوية لدى مديري مدارس التعليم الأساسي في مدينتي دمشق وعلاقتها ببعض الماته المتغيرات".

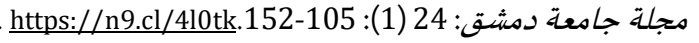

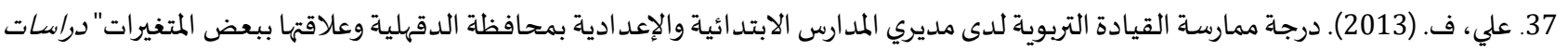
تربوية واجتماعية: 19 (1): 242-209. 38. العمايرة ، م. (2015). مبادئ الإد/رة الملمرسية. الأردن: دار الميسية:

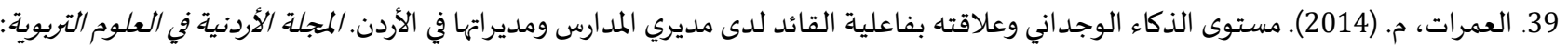
.177-190: 10 40. العمراني، ح. (2016). درجة توافر مهارات الذكاء الوجداني لدى مديرات المدارس الابتدائية الحكومية للبنات بمدينة تبوك من وجهة نظر المعلمات.

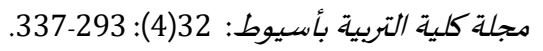

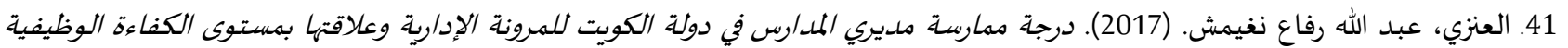
للمعلمين. (رسالة ماجستير. جامعة آل البيت). 42. عيد، ر. (2015). الكفايات والأدوار المستقبلية للقائد المدرسي. مجلة الإدارة التربوية: 2(4): 275-290. 
43. قوارح، م؛ حمايمي، ع. (2016). مدى فاعلية العلاقات الإنسانية والمهنية في نجاح الإدارة المدرسية. مجلة العلوم النفسية التويوية: 2 (2): 109-

44. المجيني، أ. (2017). دور الإدارة المدرسية في تنمية علاقة المدرسة بالمجتمع المحلي في مدارس الحلقة الثانية من التعليم الأساسي بمنطقة الباطنة (جنوب) بسلطنة عُمان. دراسات نفسية وتربوية: (19): 45. مرسي، م. (2001). الإدارة التعليمية أصهولها وتطبيقاتها. القاهرة: عالم الكتب.

46. معمار، ص؛ والصباغ، ح. (2004). فاعلية دورة مديري المدارس في تنمية القدرة على القيادة التربوية لدى مديري المدارس الابتدائية. مجلة كليات المعلمين: 4 (1)، 44-74.

47. المغاري، و. (2018). الذكاء الوجد/ني وعلاقته بالكفاءة المهنية وجودة اتخاذ القرارللدى مديري المدارس في محافظات غزة. (رسالة ماجستير).كلية

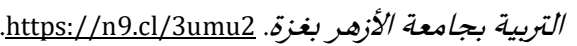

48. ملحم، ه. (2017). الذكاء الوجداني لدى مديري المدارس الثانوية الحكومية في محافظة العاصهمة عمان وعلاقتها بمستوى ممارستهم لعملية صنع القرار الأخلاقي من وجهة نظر المعلمين. (رسالة ماجستير، جامعة الشرق الوسط). كلية العلوم التربوية.

49. الهنداسي، نا. (2008). الذكاء الوجد/ني لدى مديري المدل/رس بسلطنة عُمان وعلاقته ببعض المتنغيرات الديمغرافية. (رسالة ماجستير غير منشورة). جامعة السلطان قابوس. 50. وزارة التربية والتعليم بسلطنة عُمان. (2009). دليل عمل الإدارة المملسشية. د دائرة تطوير الأداء المدرسي.

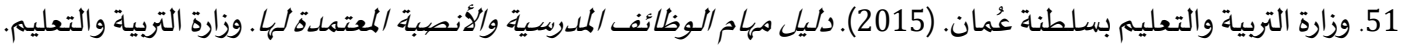
52. وزارة التربية والتعليم بسلطنة عُمان. (2012). وثيقة استمارات متابعة وتقويم أداء أعضاء الهيئات التدرليسية والإدارية والإشرافية. وزارة التربية والتعليم.

ثانياً: المراجع الأجنبية:

1. Abdullah, A. G. (2007). Emotional intelligence and leadership effectiveness of school managers in Malaysia. Educationist, 1(2): 75-81. https://n9.cl/w3550.

2. Argyris, C. (2010). Organizational traps: Leadership, culture, organizational design. New York, NY: Oxford University Press.

3. Berkovich, I., \& Eyal, O. (2015). Educational leaders and emotions: An international review of empirical evidence $1992-$ 2012. Review of Educational Research, 85(1): 129-167. https://n9.cl/k587g.

4. Brennan, J., \& Ruairc, G. M. (2011). Taking it personally: Examining patterns of emotional practice in leading primary schools in the republic of Ireland. International Journal of Leadership in Education, 14(2): 129-150 https://doi.org/10.1080/13603124.2010.536261

5. Bumphus, A. T. (2008). The emotional intelligence and resilience of school leaders: An investigation into leadership behaviors. https://2u.pw/Ms36v.

6. Burbach, M. E. (2004). Testing the relationship between emotional intelligence and full-range leadership as moderated by cognitive style and self-concept (Doctoral dissertation, The University of Nebraska-Lincoln). https://n9.cl/6dfs5.

7. Cherniss, C. (2001). Emotional intelligence and organizational effectiveness. The emotionally intelligent workplace: How to select for, measure, and improve emotional intelligence in individuals, groups, and organizations, 27-44. https://n9.cl/qdi0.

8. Cliffe, J. (2011). Emotional intelligence: A study of female secondary school headteachers. Educational Management Administration \& Leadership, 39(2): 205-218. https://doi.org/10.1177/1741143210390057

9. Coleman, M. (2005). Gender and Secondary School Leadership. International Studies in Educational Administration, 33(2).

10. Dhillon, S. (2018). Emotional Intelligence: A Comparative study on Age and Gender Differences. International journal of basic and applied research, 8(9). https://n9.cl/1vimj.

11. Eagly, A. H., \& Carli, L. L. (2003). The female leadership advantage: An evaluation of the evidence. The leadership quarterly, 14(6): 807-834. https://doi.org/10.1016/j.leaqua.2003.09.004

12. Eagly, A. H., \& Johnson, B. T. (1990). Gender and leadership style: A meta-analysis. Psychological bulletin, 108(2): 233-256. https://doi.org/10.1037/0033-2909.108.2.233

13. Eagly, A. H., Karau, S. J., \& Johnson, B. T. (1992). Gender and leadership style among school principals: A metaanalysis. Educational Administration Quarterly, 28(1): 76-102. https://doi.org/10.1177/0013161x92028001004

14. Farah bakhsh, S. (2012). The role of emotional intelligence in increasing quality of work life in school principals. ProcediaSocial and Behavioral Sciences, 46: 31-35. https://doi.org/10.1016/j.sbspro.2012.05.062

15. Fitzgerald,T. (2003). Changing the deafening silence of indigenous women's voices in educational leadership. Journal of Educational Administration, 41(1): 9-23. https://doi.org/10.1108/09578230310457402 
16. Fullan, M. (2007). Leading in a culture of change. John Wiley \& Sons. https://n9.cl/5505.

17. Goldring, E., Huff, J., May, H., \& Camburn, E. (2008). School context and individual characteristics: what influences principal practice? Journal of Educational Administration. 46 (3): 332-352. https://doi.org/10.1108/09578230810869275

18. Goleman, D., Boyatzis, R. E., \& McKee, A. (2002). The new leaders: Transforming the art of leadership into the science of results. Boston: Harvard Business School Press.

19. Grubb, W., \& Flessa, J. (2006). A job too big for one.: Multiple principals and other nontraditional approaches to school leadership. Educational Administration Quarterly, 42(4): 518-550. https://doi.org/10.1177/0013161x06290641

20. Gutierrez, A. F. (2017). The impact of emotional intelligence on the leadership of public-school superintendents (Doctoral dissertation, Brandman University). https://n9.cl/dwvqs.

21. Hallinger, P. (2011). A review of three decades of doctoral studies using the principal instructional management rating sca le: A lens on methodological progress in educational leadership. Educational Administration Quarterly, 47(2): 271-306. https://doi.org/10.1177/0013161x10383412

22. Hallinger, P., Dongyu, L., \& Wang, W. C. (2016). Gender differences in instructional leadership: A meta-analytic review of studies using the principal instructional management rating scale. Educational Administration Quarterly, 52(4): 567-601. https://doi.org/10.1177/0013161x16638430

23. Hanlin, D. C. (2014). The relationship between research-based leadership practices and emotional intelligence of high school principals (Doctoral dissertation). https://n9.cl/f9r8.

24. Hargreaves, A. (2000). Mixed emotions: Teachers' perceptions of their interactions with students. Teaching and teacher education, 16(8): 811-826. https://doi.org/10.1016/s0742-051x(00)00028-7

25. Hebert, E. B. (2011). The relationship between emotional intelligence, transformational leadership, and effectiveness in school principals. https://2u.pw/NLdlM.

26. Humphrey, R. H. (2002). The Many Faces of Emotional Leadership. The Leadership Quarterly, 13(5): 493-504. https://doi.org/10.1016/s1048-9843(02)00140-6

27. Johnson, L. (2019). Great Leaders are Sensitive. SIGMA Assessment Systems. https://n9.cl/6j17o.

28. Keith, M. A. (2009). The Lived Experiences of Secondary School Principals with Respect to Their Perceptions of the Influence of Emotional Intelligence on Their Leadership: A Phenomenological Study, ProQuest LLC, Ed.D. Dissertation, Lamar University-Beaumont. https://n9.cl/5gg22.

29. Kis, A., and N. Konan. (2014). A Meta-Analysis of Gender Differences in Terms of Teacher Views on the Instructional Leadership Behavior of Principals. Educational Sciences: Theory and Practice, 14 (6): 2139-2145.

30. Krüger, M. L. (2008). School Leadership, Sex and Gender: Welcome to Difference. International Journal of Leadership in Education. 11 (2): 155-168. https://doi.org/10.1080/13603120701576266

31. Mak, R. (2014). EQ, Not Just IQ: The Relationship between Emotional Intelligence and the Success of High School Principals Who Have Been Awarded the Illinois Principals Association's High School Principal of the Year Award. (Dissertations Doctor). Loyola University Chicago.

32. Maulding, W. S., Peters, G. B., Roberts, J., Leonard, E., \& Sparkman, L. (2012). Emotional intelligence and resilience as predictors of leadership in school administrators. Journal of Leadership Studies, 5(4): 20-29. https://doi.org/10.1002/jls.20240

33. Maulod, S. A., Piaw, C. Y., Alias, S., \& Wei, L. M. (2017). Relationship between principals' emotional intelligence and instructional leadership practices in Malaysian secondary schools. International Journal of Advanced and Applied Sciences, 4(3): 122-129.

34. Mayer, J. D., \& Geher, G. (1996). Emotional intelligence and the identification of emotion. Intelligence, 22(2): 89-113. https://doi.org/10.1016/s0160-2896(96)90011-2

35. Mayer, J. D., \& Salovey, P. (1997). What is emotional intelligence? In P. Salovey, \& D. J. Sluyter (Eds.), Emotional development and emotional intelligence: Educational implications (pp. 3-31). New York, NY. Basic Books.

36. Oluremi, O. F. (2008). PRINCIPALS'LEADERSHIP BEHAVIOUR AND SCHOOL LEARNING CULTURE IN EKITI STATE SECONDARY SCHOOLS. Journal of International Social Research, 1(3).

37. Puffer, K. A. (2011). Emotional intelligence as a salient predictor for collegians' career decision making. Journal of Career Assessment, 19(2): 130-150. https://doi.org/10.1177/1069072710385545

38. Pyszczynski, T., Holt, K., \& Greenberg, J. (1987). Depression, self-focused attention, and expectancies for positive and negative future life events for self and others. Journal of Personality and Social Psychology, 52(5): 9941001. https://doi.org/10.1037/0022-3514.52.5.994

39. Rafeedali, E. (2017). Influence of Self Concept and Emotional Maturity on Leadership Behaviour of secondary school Heads in Kerala. European Journal of Education Studies, 3(1): 295-312.

40. Sammons, S. (1999). School effectiveness: coming of age in the 21st century. Sage Journals, 13(5): 10-13. https://doi.org/10.1177/089202069901300504 
41. Shahzad, S., \& Bagum, N. (2012). Gender differences in trait emotional intelligence: A comparative study. Business Review, 7(2): 106-112.

42. Shaked, H., Glanz, J., \& Gross, Z. (2018). Gender differences in instructional leadership: how male and female principals perform their instructional leadership role. School Leadership \& Management, 38(4): 417-434. https://doi.org/10.1080/13632434.2018.1427569

43. Shanmugam, M., Amaratunga, R. D. G., \& Haigh, R. P. (2007). Leadership Styles: Gender similarities, differences, and perceptions. In 7th International Postgraduate Research Conference in the Built and Human Environment. 28th - 29th March 2007, Salford Quays, UK. https://n9.cl/kyu1n.

44. Singh, Dalip, (2006). Emotional Intelligence at Work, New Delhi, SAGE Publications Pvt. Ltd; Fourth edition.

45. Srivastava, K. (2013). Emotional intelligence and organizational effectiveness. Industrial psychiatry journal, $22(2), 97$.

46. Stets, J. E., \& Turner, J. H. (2008). The sociology of emotions. In M. Lewis, J. M. Haviland-Jones, \& L. Feldman Barret (Eds.), Handbook of emotions, (pp. 32-46). New York, NY: Guilford Press. 


$$
\text { المجلة الدولية للدراسـات التربوية والنفسية }
$$

International Journal of Educational \& Psychological Studies (EPS)

Journal Homepage: https://www.refaad.com/views/EPSR/Home.aspx

www.refaad.com

ISSN: 2520-4149 (Online) 2520-4130 (Print)

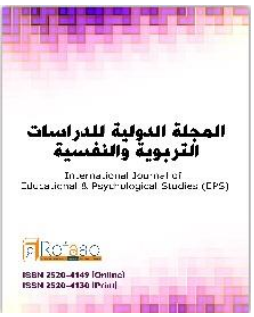

\title{
The effect of emotional intelligence on the ability of educational leadership among school principals in the Sultanate of Oman
}

\author{
Hamed Hamood Sulaiman AL Ghafri
}

Assistant Professor at the Arab Open University, Oman hamad@aou.edu.om

\author{
Received : 20/6/2021 Revised : 30/6/2021 Accepted : 6/7/2021 DOI : https://doi.org/10.31559/EPS2021.10.2.2
}

Abstract: The aim of the current study is to learn about the impact of the dimensions of emotional intelligence (emotional sensitivity, emotional maturity, emotional competence) on the dimensions of leadership (objectivity, use of power, flexibility, understanding of others, knowledge of communication principles) among school principals in the Sultanate of Oman. And to analyze the differences between emotional intelligence and educational leadership according to variables (gender, educational district). The study sample comprised 336 male and female principals, selected in a random manner. The researcher used the descriptive curriculum, the Dalip Singh scale (2006) for emotional intelligence, and the Morsi scale (2001) for educational leadership. The data was analyzed through descriptive statistics and multiple linear regression, and multi-variable contrast analysis using SPSS. The results showed: There is an impact of emotional intelligence on the ability of educational leadership. There are statistically significant differences between the gender-specific dimension of affective sensitivity in favor of females. As for the differences according to the gender variable, the results showed statistically significant differences between the two dimensions and knowledge of the principles of communication in favor of females, and the absence of differences between the other dimensions. There were no differences according to the district variable except for the Authority

Keywords Emotional Intelligence; Capacity for Educational Leadership; School principals; Leadership Skills- school principals.

\section{References:}

1. Ahmd, A. (2000). Aljwanb Alslwkyh Fy Aledarh Almdrsyh. Alqahrh: Dar Alfkr Al'rby.

2. Ahmd, A. (2008). Al'laqat Alensanyh Fy Aledarh Almdrsyh. Aleskndryh: Dar Alwfa' Ldnya Altba'h Walnshr.

3. Ambws'ydyh, M. (2012). Ttwyr Edarh Mdars Alt'lym Alasasy Fy Dw' Mdkhl Altkhtyt Alastratyjy Bsltnh 'man. (Rsalt Majstyr Ghyr Mnshwrh). Jam't Nzwa.

4. Bkhary , S, W Ahmd, '. (2015). Msadr Alslth Alty Ystkhdmha Mdyry Almars Althanwyh Alkhash Fy Tnfyd Mhamhm Bmhlyh Am Drma Balswdan Mn Wjht Nzr Alm'lmyn. Mjlt Klyt Altrbyh: (163): 489-534.

5. Alblwshyh, A. (2007). Ttwyr Almmarsat Aledaryh Lmdyr Almdars Fy Sltnt 'uman Fy Dw' Mdkhl Aldka' Alwjdany. (Rsalt Majstyr Ghyr Mnshwrh). Jam't Alsltan Qabws.

6. Brwal , M. (2015). Alkfa'h Altwaslyh Fy Aledarh Almdrsyh Fy Dw' Ara' Asatdh Alt'lym Althanwy. Mjlt Al'lwm Alnfsyh Waltrbwyh: 1(1): 109-138.

7. Albws'ydy, H. (2011). Alkfayat Aledaryh Lda Mdyry Mdars Alt'lym Alasasy Fy Dw' Mttlbat Mdrsh Almstqbl Fy Sltnt 'uman. (Rsalt Majstyr Ghyr Mnshwrh). Jam't M'th.

8. Dwghan, N؛ Walzfry, S. (2016). M'tqdat Alkfa'h Aldatyh W'laqtha Baldka' Alwjdany Wb'd Almtghyrat Alshkhsyh Walmdrsyh Lda Aledaryyn Altrbwyyn Fy Sltnt 'uman, Al'lwm Altrbwyh: 24(3): 285-310.

9. Ebrahym, M. (2018). Althlyl Alehsa'y Llbyanat Mn Almrhlh Alabtda'yh Ela Almtqdmh Bastkhdam Alhzmh Alehsa'yh Ll'lwm Alensanyh Spss. Malyzya: Jam't Al'lwm Alaslamyh Almalyzyh.

10. Hbyshy, '. (2012). Qyas Alqdrh 'la Alqyadh Altrbwyh Lmdyry Wmdyrat Almdars Althanwyh Fy Mhafzt 'dn. Mjlt Klyt Altrbyh:(12): 143-167. 
11. Alhmdany, R. (2014). Alebda' Alanf'aly W'laqth Balqyadh Altrbwyh Lda Mdra' Almdars Althanwyh. Mjlt Jrsh Llbhwth Waldrasat Alardn: 15 (2): 17-35.

12. Alhrahshh, M. (2013). Drjt Aldka' Alwjdany Lda Mdyry Mdars Mdyryh Altrbyh Walt'lym Llwa' Qsbt Mhafzt Almfrq Fy Alardn. Mjlt Almnarh: 19 (3): 353-383.

13. Hryzy , M. (2013). Drash Nqdyh Lb'd Almnahj Alwsfyh Wmwdw'atha Fy Albhwth Alajtma'yh Waltrbwyh Walnfsyh". Mjlt Al'lwm Alensanyh Walajtma'yh: (13): 23-34.

14. Aljabryh, Y. (2017). Mharat Altwasl Lda Mdyry Mdars Alhlqh Althanyh Bsltnt 'uman W'laqtha Bb'd Almtghyrat. (Rsalt Majstyr Ghyr Mnshwrh). Jam't Nzwa.

15. Jlal, Kh. (2010). Asalyb Atkhad Alqrar Wtqdyr Aldat Lda Kl Mn Mdyry Almdars Wtlab Aljam'h. Alm'tmr Aleqlymy Althany L'Im Alnfs, Alqahrh: Rabtt Alakhsa'yyn Alnfsyyn Almsryh. https://n9.cl/ubl3.

16. Khlf Allh, M. (2016). Aldka' Alwjdany Lda Mdyry Almdars Alasasyh Bmhafzh Khan Ywns W'laqth Bslwk Almwatnh Altnzymyh Lda M'lmyhm. Mjlt Aljam'h Aleslamyh Lldrasat Altrbwyh Walnfsyh: 24(3): 129-151.

17. Khlyl, Nbyl S'd. (2014). Edart Alm'ssat Altrbwyh Fy Bdayat Alalfyh Althalthh. Alqahrh: Dar Alfjr Llnshr Waltwzy'. Https://N9.Cl/2m7g3.

18. Abw Alkhyr, A, Wabw Sh'eyrh, N. (2018). Mstwa Aldka' Alwjdany W'laqth Bthsyn Ada' Mdyr Almdars Fy Almrhlh Alasasyh Aldnya Altab'h Lwkalh Alghwth Bmntqh Ghrb Ghzh Alt'lymyh. Almjlh Aldwlyh Lldrasat Altrbwyh Walnfsyh: 3(2): $198-214$.

19. Rzq, R: Walsyd, M. (2013). Mkwnat Aldka' Alwjdany W'laqtha Bmharat Atkhad Alqrar Lda Mdyry Almdars. Almjlh Altrbwyh: (34): 223-272.

20. S'adh, R. (2016). Aldka' Alwjdany Fy 'laqth Balqdrh 'la Alqyadh Altrbwyh Lda Mdyry Alm'ssat Alt'lymyh. Almjlh Altwnsyh Ll'lwm Alajtma'yh: 51 (143): 71-92.

21. S'adh, R. (2005). Aldka' Alanf'aly W'laqth Balqyadh Altrbwyh Lda Mdyry Alt'lym Alekmaly Walthanwy. (Rsalt Majstyr). Klyt Aladab Wal'lwm Alensanyh. Jam't Wrqlh, Aljza'r.

22. Als'wd, R. (2013). Alqyadh Altrbwyh (Mfahym Wafaq). Alardn: Dar Sfa' Llnshr Waltwzy'.

23. Salm, B. (2015). Aldka' Al'atfy Lmdyry Almdars Althanwyh Bmhafzat Ghzh W'laqth Balwla' Altnzymy Llm'lmyn. (Rsalt Majstyr, Akadymyh Aledarh Walsyash Lldrasat Al'lya Bghzh). https://n9.cl/8w0z.

24. Alshaman, A. (2006). Mda Fa'lyt Aldka' Alwjdany Fy Ttwyr Mharat Alqyadh Altrbwyh. Mjlt Jam't Alamam Mhmd Bn S'wd Aleslamyh: (55): 470-517.

25. Shahyn, '. (2011). Drjh Mmarsh Almdyryn Aljdd Llmharat Alqyadyh Fy Almdars Alhkwmyh Bmhafzat Ghzh Mn Wjht Nzrhm Wsbl Tnmytha. (Rsalt Majstyr, Aljam'h Aleslamyh Bghzh). https://n9.cl/aqm8.

26. Alshmry, R. (2016). Drjt Mmarsh Ab'ad Aldka' Alwjdany Lda Alqyadat Altrbwyh Fy Almdars Alahlyh Balryad. Mjlt Klyt Altrbyh: Jam't Alazhr, 168 (1): 143-174.

27. Abwshry'h, Mhmd, Jwyfl, Wmstfa, Walhsnat, Hsn. (2017). Anmat Alslwk Alqyady W'laqth Btfwyd Alslth Lda Mdyry Wmdyrat Almdars Fy Mdyryty Trbyh Albadyh Aljnwbyh Wm'an Fy Alardn Mn Wjht Nzr Alm'lmyn Walm'lmat. Mjlh Jam't Alhsyn Bn Tlal Llbhwth: 3(2): 128-159. https://n9.cl/5pd9h.

28. Skr, N. (2019). Mstwa Aldka' Alwjdany Lda Mdyry Almdars Alhkwmyh Bmdynh Ghzh W'laqth Bdrjh Alnjah Fy Mmarsath Alqyadyh Mn Wjht Nzr Alm'lmyn. Mjlh Drasat Al'lwm Altrbwyh Aljam'h Alardnyh: 2(2): 601-623.

29. Alz'anyn, B. (2018). Drjt Mmarsh Mdyry Almdars Ale'dadyh Bwkalh Alghwth Aldwlyh Bmhafzat Ghzh Llmrwnh Aledaryh W'elaqtha Btmyz Ada' M'elmyhm (Rsalh Majstyr, Aljam'eh Aleslamyh Bghzh). https://n9.cl/ayoju.

30. Alzwman, M. (2014). Mstwa Aldka' Alwjdany Lda Alqadh, Drash Mydanyh 'la Alajhzh Alhkwmyh Balmmlkh Al'rbyh Als'wdyh. Alqahrh: Alm'ssh Al'rbyh Lltnmyh Aledaryh. 